\title{
Presidentes e Congresso Nacional no Processo Decisório da Política de Saúde no Brasil Democrático (1985-1998)*
}

\author{
Marta M. Assumpção Rodrigues \\ Eduardo Meira Zauli
}

$\mathrm{E}$ ste artigo focaliza a dinâmica da relação Executivo-Legislativo no processo decisório da política de saúde no período entre a transição democrática (1985) e o final do primeiro mandato do presidente Fernando Henrique Cardoso (1998). Nosso objetivo é discutir, a partir de dados relativos à produção legislativa na área de saúde, a proposição de que presidentes que têm primazia no processo legislativo, porque dispõem de amplos poderes constitucionais para legislar (como poder de decreto), são "fortes". Ao contrário do que indica a literatura especializada no tema (Figueiredo, 1995; Figueiredo e Limongi, 1995, 1999; Power, 1998; Carey e Shugart, 1998), pretendemos demonstrar, primeiro, que a "força" de um Executivo que governa praticamente à margem da instituição representativa mais importante do regime democrático - o Congresso Nacional -é, no mínimo, questionável. Segundo, que, a exemplo daquilo que vem ocorrendo no âmbito da produção legislativa na área social (Rodrigues, 1998; Santos, 1999), a preponderância do Executivo na produção de leis na área de saúde pública é relativa, já que os parlamentares brasileiros têm re-

\footnotetext{
* Os autores agradecem a Antonio J. Viana Filho (ProdASEN) pela colaboração sempre pronta e gentil e a Flávio de Araújo Cançado (PIBIC/CNPq) pela ajuda no processamento dos dados.
}

DADOS - Revista de Ciências Sociais, Rio de Janeiro, Vol. 45, nº 3, 2002, pp. 387 a 429. 
cuperado, de maneira significativa, sua capacidade "legiferante" nessa arena política.

Partimos do princípio de que a "força" de que dispõem o Executivo e o Legislativo para aprovar legislação social não está condicionada, apenas, à capacidade de ambos de utilizar os dispositivos institucionais que lhes são conferidos pela Constituição para introduzir, modificar e/ou regulamentar legislação, nem ao conteúdo das propostas apresentadas. Apesar de estes constituírem fatores não desprezíveis, acreditamos que a preponderância da Presidência da República (ou do Congresso Nacional) na arena legislativa depende, sobretudo, das estratégias adotadas pelos atores envolvidos no processo de tomada de decisão para obter aprovação de proposições legislativas e dos recursos políticos por eles utilizados.

Este trabalho está dividido em três partes. A primeira apresenta uma síntese da evolução da agenda da política social no Brasil, com ênfase na área de saúde, no período 1985-98. Nesta seção, busca-se situar de que maneira a transição democrática, a crise econômica, a reforma do Estado e a revisão do federalismo brasileiro condicionaram as mudanças no papel do Estado na área de saúde pública.

A segunda parte trata de examinar a agenda decisória da política de saúde pública no Brasil, a partir de uma análise sobre a utilização dos mecanismos institucionais disponíveis para o Executivo e o Legislativo federais introduzirem legislação na área social. O objetivo desta seção é contribuir, de uma perspectiva institucional, para o esclarecimento da dinâmica entre os Poderes no processo decisório na área da saúde pública. Para tanto, examinamos o uso que presidentes e parlamentares fizeram de alguns instrumentos constitucionais fundamentais - como medida provisória (MP), poder de veto, projeto de lei e proposta de emenda constitucional (PEC) - durante o período estudado.

A terceira parte analisa as estratégias de negociação e os recursos políticos utilizados pelos dois Poderes para aprovar legislação no Congresso Nacional. Procura-se aqui compreender como presidentes e parlamentares interagem, na prática, para introduzir, modificar e regulamentar legislação na área da política pública de saúde no Brasil.

Como presidentes e membros do Congresso Nacional interagem para produzir legislação que visa alterar o conteúdo da política de saúde? 
De quais recursos políticos o Executivo lança mão para formar coalizões e cumprir sua agenda política na área da saúde? Que instrumentos legais são utilizados com maior freqüência pelos Poderes Executivo e Legislativo para introduzir alterações na legislação sobre saúde? Qual o impacto das decisões tomadas na área das políticas de saúde sobre o funcionamento do regime democrático no Brasil? Estas são algumas das questões que nortearam a elaboração deste artigo.

\section{A EVOLUÇÃO RECENTE DA AGENDA DA POLÍTICA SOCIAL NO BRASIL}

\section{Transição Democrática, Crise Econômica e Políticas Sociais}

Durante o período de que nos ocupamos neste artigo (1985-98), em substituição à estratégia reformista conservadora ${ }^{1}$ consubstanciada no II Plano Nacional de Desenvolvimento implementado a partir do governo Geisel (1974-79), inaugura-se uma fase caracterizada por um projeto reformador que orienta o processo de redefinição das políticas públicas de corte social que, logo, se depara com um quadro de fragmentação institucional e paralisia decisória derivado do colapso da coalizão de poder que deu sustentação ao processo de transição.

Se, ao longo das cinco décadas anteriores, se constituiu no Brasil um conjunto de políticas sociais que se aproxima do modelo de produtividade e desempenho industrial (Titmuss, 1974) ou conservador (Esping-Andersen, 1990) de Estado de Bem-Estar Social, durante os anos 80 e 90, a política social brasileira tornou-se alvo de um conjunto de pressões e demandas pela sua alteração provenientes tanto do processo de transição e consolidação democrática quanto dos constrangimentos originários do quadro de crise econômica que o país enfrentava (Draibe, 1995). Por um lado, observa-se uma tendência no sentido de a questão social ganhar relevância na agenda pública da transição democrática. Trata-se de um contexto em que adquirem expressão as propostas de descentralização e de maior participação da sociedade na elaboração e implementação das políticas públicas. De outro, o quadro de pronunciada crise econômica que se manifesta ao longo dos anos 80, e que repercute de maneira pronunciada nos 90 , ao mesmo tempo que torna inadiável, em virtude da deterioração da situação social do país (idem), a adoção de políticas sociais de caráter compensatório, faz com que a ênfase na ação reformadora voltada para o equacionamento da questão social seja minimizada em função da necessidade de o novo regime democrático e os governos civis 
subseqüentes responderem aos imperativos da administração macroeconômica do país (Torre, 1987; 1993). Nesse caso, as variáveis de ajustamento econômico, ao mesmo tempo que são indutoras de ações de política social de caráter emergencial e compensatório, constituem também importantes fatores de constrangimento da ação reformadora nos anos 80 e 90 .

Particularmente na década de 90, impõe-se uma nova agenda de reformas das políticas sociais. De forma análoga ao que ocorre em outros países latino-americanos, no Brasil, a perda das condições que viabilizaram historicamente a estratégia de substituição de importações fez com que a agenda pública evoluísse no sentido da discussão da reforma do Estado como pré-requisito para a implementação de um novo modelo de desenvolvimento (Pinheiro, 1995).

A contrapelo do impulso reformista da Constituição de 1988, que indicava claramente o sentido da evolução do sistema de proteção social brasileiro em direção a um modelo redistributivo-institucional (Titmuss, 1974) ou social-democrata (Esping-Andersen, 1990) de Estado de Bem-Estar Social a ser alcançado por meio de políticas de perfil universal com oferta pública estatal de serviços e bens na área social $^{2}$, as características mais marcantes da evolução das intervenções públicas na área social, durante os anos 90, relacionam-se com os processos de descentralização e focalização dos programas de políticas sociais em meio a um quadro de fortes restrições fiscais, o que faz com que o padrão brasileiro de proteção social se afaste também das configurações residuais (Titmuss, 1974) ou liberais (EspingAndersen, 1990) do Estado de Bem-Estar Social (Draibe, 1995; 1997; Draibe et alii, 1991).

\section{Federalismo e Políticas Sociais}

Desde o início do processo de redemocratização brasileiro, e ainda durante os anos 90, a agenda pública nacional refletiu as demandas por descentralização fiscal e das políticas sociais. Tendo como contraponto o padrão centralizado de elaboração e implementação de políticas dos governos autoritários anteriores, a bandeira da descentralização foi associada à construção da democracia e à necessidade de maior eficiência das intervenções governamentais (Abrucio, 2001; Arretche, 1996). 
Em um contexto de pronunciada fragilidade política e econômica da União, a dinâmica da evolução do sistema político e do federalismo brasileiro foi profundamente afetada pela crescente afirmação dos governadores no cenário político nacional - como demonstraram os resultados das eleições estaduais de 1982. Em meio ao processo de transição política, a realização de eleições diretas nos municípios e estados, antes da efetuação de um pleito de caráter nacional (que só ocorrerá, por via indireta, em 1984, com a vitória de grupos de oposição em importantes estados da federação), permitirá que a estrutura do federalismo consagrada durante o ciclo de governos militares seja questionada em nome da introdução de maiores níveis de autonomia dos governos subnacionais diante do poder da União.

Na esteira da emergência e afirmação do que foi qualificado como um "federalismo estadualista" (Abrucio, 1994; Abrucio e Samuels, 1997), além de promover a criação de três novos estados (Amapá, Roraima e Tocantins), a Constituição de 1988 consagrou um novo padrão de relações intergovernamentais entre estados, municípios e União ao reconhecer os municípios e o Distrito Federal como entes federados, assegurar maior autonomia e capacidade extrativa fiscal aos estados e municípios e estabelecer um aumento das transferências constitucionais da União em favor dos governos subnacionais (Kugelmas, 2001; Kugelmas e Sola, 2000).

Entretanto, em que pese o viés "estadualista" presente na evolução recente do federalismo brasileiro, a elevação dos municípios à condição de entes federados e o crescimento, em termos absolutos e em relação ao Produto Interno Bruto - PIB, de sua receita disponível vis-à-vis os recursos fiscais em mãos dos estados e da União foram interpretados como componentes de um "federalismo municipal". Afinal, a criação desses novos municípios não favoreceu uma situação de independência destes, quanto a suas receitas, das transferências constitucionais e de convênios com os estados e com a União (Gomes e MacDowell, 2000).

De fato, um aspecto saliente da dinâmica do federalismo brasileiro nas duas últimas décadas aponta para um quadro de redistribuição vertical dos recursos fiscais da União em favor dos estados e municípios, e dos estados em favor dos municípios (Serra e Afonso, 1999). A propósito, entre 1989 e 1996, verifica-se um quadro de crescimento negativo da receita tributária disponível da União (de 61,1\% para 
$56,4 \%)$ e de crescimento positivo das receitas disponíveis de estados (de $25 \%$ para $27 \%$ ) e municípios (de $13,9 \%$ para $16,7 \%$ ), - para o ano de 1995, enquanto a arrecadação direta de estados e municípios foi da ordem de $34 \%$ da carga tributária global, depois de realizadas todas as transferências em seu favor, estes passaram a dispor de $44 \%$ da receita tributária (Afonso e Lobo, 1996).

Tudo isso em meio a um sistema federativo cujos dispositivos institucionais operam no sentido tanto da restrição do poder central quanto do poder do demos. A propósito, Stepan (1999) elabora a idéia de que em um continuum de federações democráticas mais ou menos restritivas do poder da maioria (demos constraining) e federações que mais ou menos ampliam o poder do conjunto de seus cidadãos (demos enabling), o Brasil ocupa uma posição extrema no continuum demos constraining.

Não tendo a Constituição de 1988 promovido uma revisão da distribuição dos diferentes encargos governamentais coerente com o novo padrão de repartição dos recursos fiscais entre os entes federativos (Serra e Afonso, 1999; Abrucio, 2001; Abrucio e Samuels, 1997), e diante do agravamento da situação fiscal da União, verifica-se, durante os anos 90, que o governo central - sob o impacto da federalização e renegociação das dívidas de estados e municípios e em meio a importantes restrições fiscais - passa a atuar em duas frentes. Por um lado, procede à recomposição de sua base de recursos através do Fundo Social de Emergência - FSE (depois Fundo de Estabilização Fiscal - FEF) e do aumento da arrecadação através de contribuições sociais - cuja receita não é partilhada com estados e municípios; por outro, procede à operacionalização de um amplo conjunto de medidas de descentralização pela oferta ${ }^{4}$, com destaque para as políticas públicas na área de saúde.

\section{O Setor de Saúde}

Até meados dos anos 60, as políticas para o setor de saúde foram fortemente influenciadas por arranjos institucionais de tipo corporativista estatal conjugados com um modelo de seguro-saúde de base contributiva com importantes restrições de acesso em relação à população não-contribuinte ${ }^{5}$. Já durante o ciclo de governos militares, a unificação dos diferentes regimes de previdência social em 1966 com a criação do Instituto Nacional de Previdência Social - INPS e a 
incorporação dos trabalhadores rurais (1971), das empregadas domésticas (1972) e dos trabalhadores autônomos (1973), entre outros segmentos sociais, ao regime previdenciário vigente-, promove um avanço decisivo em direção à universalização de determinados direitos sociais (Costa, 1996; Draibe, 1994; Draibe et alli, 1991; Malloy, 1986; Salm e Coutinho, 1986; Schmitter, 1974).

Durante os anos 80 , as significativas mudanças institucionais e na agenda pública relativas à área de saúde no Brasil, na direção de níveis mais abrangentes de universalização das políticas do setor, refletem as realizações dos governos autoritários anteriores no sentido da superação da institucionalidade fragmentária e excludente de um certo padrão de acesso aos bens e serviços de saúde pelas diferentes camadas da população. Nesse período, no âmbito das políticas sociais, o setor de saúde constitui-se na área de políticas públicas que conheceu as maiores mudanças, particularmente com a promulgação da Constituição de 1988. Reflexo dos deslocamentos observados no eixo analítico de problematização das políticas sociais, as mudanças no setor de saúde acompanham pari passu a dinâmica de evolução da agenda pública no Brasil nas últimas décadas.

Embora as conseqüências das ações reformadoras/descentralizadoras no campo das políticas sociais, por parte dos Executivos federais, desde os anos 80, estejam longe de constituir um quadro homogêneo, com grande variação de resultados uma vez que se trata de políticas sociais diferentes, assim como com importantes distinções entre as unidades da federação brasileira no que se refere à participação dos estados e municípios na gestão das políticas de saúde (Almeida, 1995; Arretche, 1999) ${ }^{6}$, o fato é que, em meio ao processo de transição democrática, a agenda pública na área de saúde termina por sofrer uma nova inflexão com a incorporação de novos temas associados à emergência e à afirmação de novos atores no quadro político nacional.

Nesse contexto, adquire particular relevância a agenda reformista proposta pelos diferentes atores que integravam o movimento sanitarista, cujas proposições no sentido da promoção da descentralização da gestão dos serviços de saúde serão amplamente ratificadas no âmbito da VIII Conferência Nacional de Saúde (1986).

De fato, as mais importantes inovações consubstanciadas na Constituição de 1988 são fruto do processo de interação de uma gama diver- 
sificada de atores sociais que acaba por repercutir nos trabalhos da Assembléia Nacional Constituinte em um contexto de mudanças na agenda pública nacional. Observa-se, já a partir de 1984, uma reorientação na análise do modus operandi da política social brasileira que submete à crítica seus aspectos centralizador, excludente e ineficaz, dentre outros. Nesse diapasão, a ênfase na abertura das arenas decisórias das políticas públicas à participação de atores até então excluídos das mesmas, e na descentralização das intervenções públicas na área social, constitui-se em leitmotiv da ação reformadora nessa área de políticas públicas. Com efeito, em meio a um ambiente de crítica ao padrão de intervenção estatal perpetrado na área social durante o ciclo de governos militares, e diante do momento fundacional propiciado pela elaboração de uma nova Constituição, configura-se uma importante policy window ${ }^{7}$ (Kingdon, 1993), em torno da qual diferentes atores se mobilizam no sentido de influenciar na reconfiguração do perfil das políticas de saúde.

Ao longo desse período, a criação do Sistema Único de Saúde - SUS configura-se como a mais importante iniciativa de reforma na área social. Coroando um processo que remonta ao início dos anos 80 , a constituição do SUS foi precedida pela implantação das Ações Integradas de Saúde (1984) e pela instituição do Sistema Unificado e Descentralizado de Saúde-SUDS (1987). Exemplo de um processo de descentralização que contou com forte apoio institucional do governo central e, ao mesmo tempo, expressou um amplo conjunto de demandas vocalizadas por diferentes atores sociais, a implantação do SUS ocorre no contexto da redemocratização e de fortalecimento das bases federativas do sistema político brasileiro (Almeida, 1995; Arretche, 1998).

Após a aprovação da Lei Orgânica da Saúde - LOS, tem início nos 90 um processo de normatização e institucionalização da orientação descentralizadora do SUS. Por intermédio das Normas Operacionais Básicas - NOBs, o Ministério da Saúde paulatinamente define as regras do seu funcionamento, explicitando as diferentes modalidades de habilitação de estados e municípios na gestão dos recursos do SUS (Arretche, 1998; Augusto e Costa, 2000).

Nesse período, em meio a uma severa crise fiscal em boa medida herdada dos governos anteriores, abre-se uma nova policy window, com um novo deslocamento da agenda pública nacional no sentido da discussão da reforma do Estado que envolve a redefinição de seu papel 
no que diz respeito à configuração das políticas sociais. Entre outros temas, assiste-se, então, à proliferação de estudos voltados para alterações do mix público-privado e a adoção de políticas seletivas e de focalização do gasto público (Melo, 1998; 1999). Ainda nessa fase, em uma nova rodada de discussões sobre as bases de financiamento das políticas de saúde e no decurso da implementação de uma série de reformas setoriais, destaca-se a desvinculação do orçamento da Previdência Social do Fundo da Seguridade Social tal qual definida pela Constituição de 1988.

\section{A AGENDA DECISÓRIA DA POLÍTICA DE SAÚDE PÚBLICA NO BRASIL}

Dado o escopo deste artigo, a análise do conteúdo da política de saúde pública que foi implementada no país e a caracterização do ambiente em que foram formuladas diversas decisões políticas entre 1985 e 1998 requerem um exame dos mecanismos institucionais passíveis de serem utilizados pelos membros do Executivo e Legislativo tendo em vista a produção legislativa. Para tanto, procede-se nesta seção a uma reconstituição dos processos decisório e de estabelecimento das regras constitucionais, leis, decretos presidenciais, normas operacionais e produção legislativa que vêm regulamentando a institucionalização do sistema de prestação de serviços de saúde. A descrição apresentada aqui se baseia nos fundamentos constitucionais da política descentralizada de saúde, no conteúdo da LOS e em alguns atos normativos editados pelo Poder Executivo ${ }^{8}$.

\section{Arcabouço Institucional da Descentralização}

Desde a transição democrática, em 1985, um conjunto de leis, decretos presidenciais, normas operacionais e portarias ministeriais vem regulamentando um longo processo de institucionalização de novas regras e procedimentos no âmbito do sistema de prestação de serviços de saúde no país ${ }^{9}$. Entretanto, o marco inaugural mais importante para a redefinição das prioridades das ações estatais destinadas ao atendimento das necessidades da população na área da saúde pública, assim como para a ampliação da autonomia de gestão das autoridades públicas locais, foi a Constituição de 1988.

O texto final da Carta de 1988, no capítulo referente à saúde pública (artigos 196 a 200), reconhece a saúde como um direito social de todos os cidadãos - garantido pelo acesso universal e igualitário às ações e 
serviços para promoção, proteção e prevenção de saúde--, e como um dever do Estado - através da elaboração de políticas e programas sociais que visam à redução do risco de doenças. Contudo, o primeiro passo para a institucionalização do sistema proposto no texto constitucional de 1988 só foi dado na administração do presidente Fernando Collor de Mello (1990-92). Em 7 de agosto de 1990, Collor edita o decreto presidencial no 99.438, que organiza e define as atribuições do Conselho Nacional de Saúde. Logo em seguida (19 de setembro de 1990), foi a vez de o Congresso Nacional aprovar a Lei Orgânica da Saúde, que ratifica as diretrizes constitucionais do sistema e amplia a responsabilidade municipal na provisão dos serviços de saúde e nas atividades de negociação, alocação de recursos e regulação de desempenho. Da aprovação da LOS (Lei no 8.080) resultaram dois aspectos fundamentais:

Em primeiro lugar, ao definir as atribuições de cada esfera de governo, no que diz respeito à gestão e às competências, além de dispor sobre a organização dos serviços e o funcionamento do SUS, a Lei $n^{-}$ 8.080 acabou criando mecanismos institucionais importantes que passaram a vincular, de maneira definitiva, a descentralização à municipalização. Um segundo aspecto, de outra ordem, refere-se ao conteúdo da legislação e à dinâmica do processo decisório. A Lei no 8.080 foi aprovada com veto parcial aos artigos referentes à participação popular e ao financiamento do sistema e, apesar de o Congresso Nacional ter mantido o veto presidencial, este fato acabou gerando um impasse político entre o Executivo e o Legislativo, na medida em que questões importantes relativas ao conteúdo da legislação foram deixadas sem solução. Nesse sentido, com o intuito de facilitar a implementação do sistema em um cenário caracterizado por dificuldades tanto no relacionamento entre o Executivo e o Congresso Nacional quanto nas questões concernentes à participação popular e ao financiamento do sistema, novos arranjos institucionais foram criados.

O mais importante desses arranjos foi a aprovação da Lei Complementar no 8.142, de 28 de dezembro de 1990, que dispõe sobre as condições e as formas de transferências de recursos e a participação da comunidade na gestão do SUS, a partir da criação de duas instâncias colegiadas: o Conselho de Saúde e a Conferência de Saúde ${ }^{10}$. Estabelecido com o objetivo de avaliar a situação da saúde no país, o Conselho de Saúde constitui, até hoje, uma instância privilegiada - apesar de ainda mal aproveitada - na discussão da política de saúde, na formu- 
lação de estratégias e no controle da execução do Plano Nacional de Saúde (Rodrigues, 1999). Retomaremos este ponto adiante.

A partir de 1991, as NOBs constituíram o arranjo que passou a regulamentar a descentralização do sistema de saúde. Tendo como base o texto constitucional de 1988, a LOS e a Lei Complementar no 8.142 , ao longo do período em estudo, foram editadas pelo Executivo, através do Ministério da Saúde, três NOBs: em 1991, 1993 e 1996.

ANOB 1/91 introduziu o conceito de habilitação dos municípios e estados ao SUS, mediante comprometimento com a gestão direta de serviços, e previu a formação de um fundo setorial e o funcionamento de conselhos comunitários. Dois anos após sua edição, quando a inoperância desse arranjo institucional foi detectada pelo Ministério da Saúde, o Executivo editou uma segunda NOB (1/93) que representa, esta sim, um divisor de águas importante na política de saúde dos $\operatorname{anos} 90$.

A NOB 1/93 criou as Comissões Intergestores Tripartite (compostas por representantes dos governos federal, estadual e municipal) e Bipartite (com representação paritária entre estados e municípios), as regras de transferência de recursos e os mecanismos de controle e avaliação. Ademais, adotando o modelo de descentralização pactuada, a NOB 1/93 desenhou também três situações transacionais para a gestão do sistema de saúde (Incipiente, Parcial e Semiplena), que acabaram inaugurando o sistema de representação progressiva de titularidade governativa. Segundo a NOB 1/93, para alcançar uma dessas situações na gestão setorial, os governos locais deveriam atingir uma capacidade estatal associada a variáveis de responsabilização e controle externo das suas decisões.

O aumento da responsabilidade do governo local na gestão direta dos serviços de saúde serviu como mecanismo de aceleração da adesão dos municípios às novas funções propostas pelo SUS. Em 1996, dos 4.973 municípios brasileiros, $65,1 \%$ passaram a se enquadrar em uma das modalidades de gestão proposta pelo SUS; $49,4 \%$ habilitaram-se na Gestão Incipiente; 12,8\%, na Gestão Parcial; 2,9\%, na Gestão Semiplena (Silva et alii, 1999:40). Nesse mesmo ano, o Ministério da Saúde editou uma terceira NOB (1/96), cujo objetivo foi não só ampliar a responsabilidade dos gestores municipais e estaduais, mas também fortalecer a atenção básica e primária nas ações de saúde coletiva. 
Ao reduzir as condições de habilitação a duas modalidades (Gestão Plena da Atenção Básica - GPAB, e Gestão Plena do Sistema Municipal-GPSM), a NOB 1/96 simplificou de maneira significativa o processo de responsabilização municipal proposto na NOB anterior (1/93). O município habilitado na GPAB passou a se responsabilizar pela atenção primária de alcance coletivo (como ações básicas de vigilância sanitária) e por alguns procedimentos individuais de caráter ambulatorial (clínica médica, ginecologia, obstetrícia, pediatria e pequenas cirurgias ambulatoriais). Neste caso, a provisão das ações de saúde pode ocorrer tanto por intermédio das unidades públicas próprias, quanto pela contratação de serviços do setor privado. Por outro lado, a habilitação na GPSM deu ao gestor local autonomia suficiente para editar normas de pagamento de serviços em seu território, tendo como referência a tabela nacional do SUS. O gestor passa então a ser responsável pela programação, controle e remuneração dos serviços produzidos localmente, independentemente do tipo de provedor (público ou privado).

Assim como ocorreu com a edição da NOB 1/93, da NOB 1/96 resultou também um incremento significativo na adesão dos municípios brasileiros à descentralização. Dados do Ministério da Saúde indicam que, até a metade de 1998, 4.664 municípios brasileiros estavam habilitados em uma das duas formas de gestão descentralizada propostas pela NOB 1/ 96 (GPAB ou GPSM). Em contrapartida, no mesmo período, o Ministério da Saúde já havia transferido recursos correspondentes a cerca de $30 \%$ do dispêndio federal com assistência médico-ambulatorial (Silva et alii, 1999:44). É a partir desse arcabouço institucional que ocorre a consolidação da política de descentralização da saúde no Brasil democrático (Augusto e Costa, 2000).

\section{Produção Legislativa e Dispositivos Institucionais}

Da perspectiva da produção legislativa, as iniciativas do Executivo e dos membros do Congresso para introduzir propostas e/ou apresentar alterações na legislação vigente na área da política social, em geral, e da saúde pública, em particular, são condicionadas por uma série de dispositivos institucionais que estruturam o espaço de interação entre o chefe do Executivo e os parlamentares. No texto da Constituição de 1988 e nos regimentos internos do Senado e da Câmara dos Deputados são definidos os dispositivos legais que organizam o processo legislativo. 
Com relação aos poderes conferidos pela Constituição de 1988 ao Executivo para introduzir e/ou modificar legislação, diversos estudos têm comprovado que Executivos com amplos poderes constitucionais de decreto são sempre muito fortes (Carey e Shugart, 1998; Mainwaring e Shugart, 1997; Figueiredo et alii, 2000 $)^{11}$. No caso do Brasil, durante o período analisado, as prerrogativas constitucionais da Presidência da República produziram de fato um Poder Executivo preponderante, em termos legislativos, porque a possibilidade de o presidente legislar através de medida provisória ${ }^{12}$ (art. 62), combinada com o instituto do veto parcial ou total (art. 66), gerou uma situação em que, na prática, boa parte da agenda do Congresso Nacional e do conteúdo das políticas aprovadas é determinada pelo Executivo federal (Schmitt, 1995; Morgenstern, 1996) ${ }^{13}$. Ademais, os efeitos de tais dispositivos constitucionais, que asseguram a preponderância do Executivo na produção legal, são reforçados ainda por certos estatutos contidos nas normas sobre o processo legislativo que operam como regras que organizam a tramitação de proposições no âmbito do Congresso Nacional: as tramitações em regime de urgência e de urgência urgentíssima ${ }^{14}$.

Apesar da "força" do Executivo brasileiro, nos termos descritos acima, dados coletados em nossa pesquisa junto ao Serviço de Processamento de Dados do Senado Federal - PRODASEN mostram que, no período entre 1985 e 1998, de um total de 82 MPs editadas (e reeditadas) pelo Executivo na área da saúde, apenas seis foram transformadas em lei. Assim, no que se refere à capacidade pró-ativa ${ }^{15}$ do Executivo brasileiro para introduzir legislação através de MP, a Tabela 1 deixa claro que, na área da saúde, os presidentes são "fortes" especialmente quando legislam à margem do Congresso, já que um número razoável de iniciativas legislativas do Executivo foi implementado (temporariamente) com força de lei e deixou de ter efeito - a partir da sua não-reedição - sem ao menos passar pela apreciação em plenário ${ }^{16}$.

Observa-se na Tabela 1 que o total de 166 peças legislativas que o Executivo brasileiro apresentou ao Congresso na área da saúde pública inclui 15 medidas provisórias originais, 67 reedições, 78 mensagens, 5 ofícios ${ }^{17}$ e uma proposta de emenda à Constituição; 34 proposições foram aprovadas pelo Congresso.

A partir destes dados podemos inferir que os custos para o Executivo introduzir legislação através de MPs são relativamente baixos, uma 
Marta M. Assumpção Rodrigues e Eduardo Meira Zauli

Tabela 1

Proposições Legislativas Apresentadas ao Congresso pelo Poder

Executivo e Aprovadas na Área da Saúde

(1985-1998)

\begin{tabular}{|c|c|c|}
\hline $\begin{array}{l}\text { Tipo de Legislação } \\
\text { Introduzida pelo } \\
\text { Executivo no Con- } \\
\text { gresso }\end{array}$ & $\begin{array}{l}\text { Número de Proposi- } \\
\text { ções Legislativas } \\
\text { Apresentadas }\end{array}$ & $\begin{array}{l}\text { Número de Leis } \\
\text { Sancionadas }\end{array}$ \\
\hline MPs originais & 15 & 4 \\
\hline MPs reeditadas & 67 & 2 \\
\hline Subtotal & 82 & 6 \\
\hline Mensagens & 78 & 27 \\
\hline Ofícios & 5 & - \\
\hline PEC & 1 & 1 \\
\hline Total & 166 & 34 \\
\hline
\end{tabular}

Fontes: Prodasen e Banco de Dados Legislativos (política de saúde) DCP/UFMG.

vez que, ao longo do tempo, os presidentes utilizaram este expediente de maneira crescente e sistemática ${ }^{18}$, ao passo que os custos para o Congresso apreciar MPs (tanto para rejeitá-las, quanto para transformá-las em PLVs ${ }^{19}$ ou em lei) são bastante altos. A Tabela 2 demonstra este ponto.

De fato, os dados da Tabela 2 evidenciam que no Brasil, durante o período estudado, os presidentes foram capazes de legislar na área da saúde praticamente à margem do Congresso - através da reedição de MPs -, ao passo que este foi relativamente incapaz de apreciar e lapidar o conteúdo das MPs propostas pelo Executivo.

Diversos fatores explicam o enfraquecimento do poder reativo do Congresso ${ }^{20}$ e da sua capacidade para determinar o output legislativo do sistema. O primeiro tem a ver com as dificuldades que o Congresso tem demonstrado em organizar de maneira eficiente as comissões especiais que devem ser formadas pelos membros das duas Casas para apreciar e/ou modificar cada MP que o Executivo edita. Para ilustrar este ponto, dados da Tabela 2 mostram que das $82 \mathrm{MPs}$ apresentadas ao Congresso entre 1988 e 1998 pelo Executivo na área de saúde pública, apenas doze passaram pelo crivo do Poder Legislativo. Destas, 
Presidentes e Congresso Nacional no Processo Decisório da Política de Saúde...

Tabela 2

Medidas Provisórias (Originais e Reeditadas) na Área da Saúde, por Administração

(1988-1998)

\begin{tabular}{l|c|c|c|c|c}
\hline & $\begin{array}{c}\text { José } \\
\text { Sarney }\end{array}$ & $\begin{array}{c}\text { Fernando } \\
\text { Collor }\end{array}$ & $\begin{array}{c}\text { Itamar } \\
\text { Franco }\end{array}$ & FHC & Total \\
\hline MPs originais & 1 & 1 & 2 & 11 & 15 \\
MPs reeditadas & 0 & 2 & 0 & 65 & 67 \\
\hline Total & $\mathbf{1}$ & $\mathbf{3}$ & $\mathbf{2}$ & $\mathbf{7 6}$ & $\mathbf{8 2}$ \\
\hline
\end{tabular}

\begin{tabular}{l|c|c|c|c|c}
\hline $\begin{array}{l}\text { MPs aprovadas sem modificação } \\
\text { MPs aprovadas com modificação }\end{array}$ & 1 & 1 & 0 & 4 & 6 \\
(PLVs) & 0 & 0 & 0 & 1 & 1 \\
MPs transformadas em PLV, mas & 0 & 1 & 1 & 0 & 2 \\
não aprovadas & 0 & 0 & 0 & 3 & 3 \\
MPs revogadas & $\mathbf{1}$ & $\mathbf{2}$ & $\mathbf{1}$ & $\mathbf{8}$ & $\mathbf{1 2}$ \\
\hline Total
\end{tabular}

Fontes: Prodasen e Banco de Dados Legislativos (política de saúde) DCP/UFMG.

seis foram aprovadas sem modificação, uma foi aprovada com modificação, duas foram transformadas em PLVs, mas não foram aprovadas, e três foram revogadas. Todo o restante, as setenta MPs editadas/reeditadas com força de lei, simplesmente, perdeu eficácia.

Além das dificuldades que o Congresso enfrenta para organizar comissões especiais, sua capacidade reativa foi bastante limitada pelo trâmite do recurso mais freqüentemente utilizado pelos congressistas, as proposições de leis ordinárias, que envolve um processo deliberativo muito mais lento do que aquele observado quando do envio pelo Executivo de mensagens ou de MPs. Dados extraídos do PRODASEN sobre a produção legislativa na área da saúde entre 1985 e 1998 mostram que a tramitação das proposições aduzidas pelo Legislativo demora, em média, quatro vezes mais tempo para ser aprovada do que aquelas propostas pelo Executivo.

Um outro fator que pode ter debilitado a capacidade legislativa do Congresso se refere ao poder reativo do Executivo ${ }^{21}$ para redesenhar a legislação que o Congresso aprova, através do veto total ou parcial. Dados fornecidos pelo PRODASEN mostram, por exemplo, que, das 55 
proposições aprovadas pelo Congresso na área e período em tela, 32 sofreram algum tipo de veto presidencial (onze vetos totais e 21 parciais). Das onze peças legislativas que sofreram veto total, três tiveram origem no Executivo e oito, no Legislativo. O Congresso conseguiu derrubar dois vetos totais das proposições que tiveram início no Legislativo e nenhum veto total das proposições provenientes do Executivo. Isto significa que, das onze proposições que o Congresso aprovou e que sofreram veto total, nove nunca foram transformadas em lei.

Com relação às 21 peças legislativas que sofreram veto parcial, doze tiveram origem no Executivo e nove no Legislativo. Seguindo o padrão anterior, nenhum veto parcial em peça legislativa introduzida pela Presidência foi derrubado, enquanto um veto parcial (sobre peça com origem no Legislativo) foi derrubado (Tabela 3).

Tabela 3

Vetos Totais e Vetos Parciais sobre Legislação Produzida na Área de Saúde, por Origem

(1985-1998)

\begin{tabular}{l|c|c|c|c}
\hline Origem & Vetos Totais & Vetos Parciais & $\begin{array}{c}\text { Vetos Totais } \\
\text { Derrubados }\end{array}$ & $\begin{array}{c}\text { Vetos Parciais } \\
\text { Derrubados }\end{array}$ \\
\hline Executivo & 3 & 12 & 0 & 0 \\
Legislativo & 8 & 9 & 2 & 1 \\
\hline Total & $\mathbf{1 1}$ & $\mathbf{2 1}$ & $\mathbf{2}$ & $\mathbf{1}$ \\
\hline
\end{tabular}

Fontes: Prodasen e Banco de Dados Legislativos (política de saúde) DCP/UFMG.

Outra explicação para o sucesso dos presidentes em conseguir aprovar um número maior de proposições do que o Congresso na área da saúde remete à natureza diversa da atividade legislativa deste último vis-à-vis a da Presidência, que constitui um corolário da literatura da escolha racional. Segundo este, enquanto o Poder Executivo como uma instância institucional propõe leis que tendem a implementar políticas de efeito "mais geral" - uma vez que as proposições legislativas introduzidas pelos presidentes contemplam "questões nacionais" -, no caso do Legislativo, o poder de alvitrar projetos de lei no Congresso é individual - na medida em que os parlamentares são movidos pelo interesse próprio de reeleição (Mayhew, 1974). De maneira que o grande número de projetos propostos no Congresso Nacional pelos legisladores e o baixo índice de aprovação destes pelo plenário 
do Congresso vão ao encontro da tese de Mayhew (idem) de que os congressistas estão interessados em apresentar o maior número possível de proposições, mas não em fazer o devido esforço para que estas sejam efetivamente aprovadas.

Sobre este tema, Nelson Jobim, ministro da Justiça na administração Fernando Henrique Cardoso, observou:

"A verdade é que os deputados oferecem projetos de lei que, muitas vezes, não visam aprovação. Estes projetos visam apenas impressionar o eleitorado do congressista que o apresenta. O projeto é apresentado apenas para ser enviado ao município do parlamentar. Estes são os chamados projetos de categorias regionais ${ }^{22}$. Como são apresentados aos montes no Congresso Nacional, projetos deste tipo acabam entulhando o processo legislativo" ${ }^{23}$.

Os dados da Tabela 4 comprovam esta tese mostrando que, apesar de os presidentes brasileiros terem introduzido, no intervalo pesquisado, apenas $15 \%$ das proposições na área da saúde no Congresso, eles foram responsáveis por $62 \%$ das leis que o Legislativo aprovou no período. Dos 976 projetos de lei introduzidos por parlamentares na área de saúde, apenas 21 foram transformados em lei $^{24}$, perfazendo um total de $38 \%$ das proposições que o Congresso aprovou.

Tabela 4

Proposições Legislativas Apresentadas ao Congresso e Sancionadas, na Área de Saúde, por Origem

(1985-1998)

\begin{tabular}{l|c|c}
\hline Origem & $\begin{array}{c}\text { Proposições Legislativas } \\
\text { Apresentadas }\end{array}$ & Leis Sancionadas \\
\hline Executivo & 166 & 34 \\
& $(15 \%)$ & $(62 \%)$ \\
Legislativo & 976 & 21 \\
& $(85 \%)$ & $(38 \%)$ \\
\hline Total & $\mathbf{1 . 1 4 2}$ & $\mathbf{5 5}$ \\
& $\mathbf{( 1 0 0 \% )}$ & $\mathbf{( 1 0 0 \% )}$ \\
\hline
\end{tabular}

Fontes: Prodasen e Banco de Dados Legislativos (política de saúde) DCP/UFMG.

Uma última explicação possível sobre a dificuldade dos parlamentares para aprovarem seus próprios projetos reside na simultaneidade dos processos de seleção e de apreciação de proposições com origem 
no Legislativo. Se, no caso do Executivo, a negociação é feita antes de as proposições legislativas irem a plenário - assim como a seleção daquelas que deverão contar com maior empenho dos congressistas para efeito de aprovação -, no caso das proposições dos congressistas, a trajetória de negociação/seleção de uma peça legislativa é feita em um único processo (Figueiredo e Limongi, 1999:55). Isto significa que as proposições iniciadas pelo Legislativo, ao contrário do que acontece no Executivo, são fruto de um processo decisório descentralizado. Nesse caso, apenas a seleção das proposições iniciadas por parlamentares é tarefa coletiva.

Sobre este ponto, Novaes (1994:139) foi pioneiro ao sugerir que, quando uma proposta do Executivo recebe tramitação de urgência, é porque foi alcançado algum tipo de acordo entre lideranças. Presidentes apresentam um projeto de lei após terem discutido seu conteúdo com os líderes partidários e presidentes de comissão (Figueiredo e Limongi, 1999), enquanto os projetos encetados pelos parlamentares devem passar por todo o trâmite seletivo do processo legislativo.

Dados apresentados na Tabela 4 deixam claro que o processo de seleção de propostas iniciadas pelos congressistas representa, pela quantidade, enorme obstáculo à eficiência do Legislativo no que diz respeito às próprias medidas que este pretende adotar, principalmente porque o processo de seleção aumenta significativamente o tempo de apreciação das propostas com origem nesse Poder.

Considerando todos os fatores apresentados aqui, que corroboram a tese da primazia do Executivo no processo decisório, cabe colocar a seguinte questão: será que os amplos poderes legislativos dos presidentes brasileiros significam, na prática, que o Executivo detém, efetivamente, a última palavra no processo decisório na área das políticas sociais?

Para responder a esta pergunta, voltamo-nos para uma pesquisa que apresenta dados agregados sobre a produção legislativa dos parlamentares na área social ${ }^{25}$, entre 1985 e 1996, que mostram que a capacidade do Congresso para legislar nessa arena política é significativamente maior do que a do Poder Executivo (Rodrigues, 1998). Para o período, tal estudo demonstra que $57 \%$ dos projetos de lei aprovados pelo Congresso Nacional na área social foram de iniciativa do Legis- 
lativo e $43 \%$, do Executivo. Estas porcentagens se tornam ainda mais significativas se considerarmos que $89 \%$ dos projetos de lei que sofreram veto total nesse interregno - e, por isso, nunca foram transformados em lei - foram principiados por membros do Congresso; quase a metade destes (49\%) eram projetos de lei relativos à área social.

A recuperação da capacidade "legiferante" do Congresso na produção legal sobre os temas de cunho social é confirmada por outra pesquisa (Santos, 1999) que desagrega dados sobre a produção legislativa dos Poderes Executivo e Legislativo, em duas áreas políticas (econômico-administrativa e social), em dois períodos distintos: 1989-94 e 1995-97 (ver Tabela 5).

Tabela 5

Leis Sancionadas por Origem nas Áreas Econômico-Administrativa e Social

(1989-94 e 1995-97)

\begin{tabular}{|c|c|c|c|c|c|c|}
\hline \multirow[t]{2}{*}{ Áreas } & \multicolumn{3}{|c|}{ 1989-94 } & \multicolumn{3}{|c|}{ 1995-97 } \\
\hline & Legislativo & Executivo & $\begin{array}{c}\text { Total } \\
(1989-94)\end{array}$ & Legislativo & Executivo & $\begin{array}{c}\text { Total } \\
(1995-97) \\
\end{array}$ \\
\hline $\begin{array}{l}\text { Econômi- } \\
\text { co-Admi- } \\
\text { nistrativa }\end{array}$ & $\begin{array}{c}35 \\
(19 \%)\end{array}$ & $\begin{array}{c}145 \\
(81 \%)\end{array}$ & $\begin{array}{c}180 \\
(100 \%)\end{array}$ & $\begin{array}{c}19 \\
(26 \%)\end{array}$ & $\begin{array}{c}53 \\
(74 \%)\end{array}$ & $\begin{array}{c}72 \\
(100 \%)\end{array}$ \\
\hline Social & $\begin{array}{c}57 \\
(53 \%) \\
\end{array}$ & $\begin{array}{c}50 \\
(47 \%) \\
\end{array}$ & $\begin{array}{c}107 \\
(100 \%) \\
\end{array}$ & $\begin{array}{c}70 \\
(80 \%) \\
\end{array}$ & $\begin{array}{c}18 \\
(20 \%) \\
\end{array}$ & $\begin{array}{c}88 \\
(100 \%) \\
\end{array}$ \\
\hline Total & $\begin{array}{c}92 \\
(32 \%) \\
\end{array}$ & $\begin{array}{c}195 \\
(68 \%) \\
\end{array}$ & $\begin{array}{c}287 \\
(100 \%)\end{array}$ & $\begin{array}{c}89 \\
(56 \%) \\
\end{array}$ & $\begin{array}{c}71 \\
(44 \%) \\
\end{array}$ & $\begin{array}{c}160 \\
(100 \%) \\
\end{array}$ \\
\hline
\end{tabular}

Fontes: Período 1989-94: Prodasen; Banco de Dados Legislativos (Cebrap). Período 1995-97: ProdAsEN (apud Santos, 1999).

A partir dos dados contidos na Tabela 5, podemos inferir que, no período analisado, as intervenções dos membros do Congresso concentraram-se, principalmente, em temas de cunho social, e que os parlamentares têm sido responsáveis por um número cada vez maior de proposições aprovadas na área social. Isto, de certa forma, desqualifica a tese de Mayhew (de que as proposições iniciadas pelo Executivo tendem a ser, em geral, institucionais; enquanto aquelas introduzidas pelos congressistas, mais individuais), pelo menos no que se refere à área social. Segundo o ministro da Educação do governo FHC, Paulo Renato de Souza ${ }^{26}$, uma explicação para esse dado se encontra no fato de que as iniciativas legislativas do Poder Executivo 
“[...] são mais realistas [do que as dos parlamentares], porque toda proposta do Executivo analisa necessariamente a questão do recurso e o Congresso não se preocupa com o recurso. No Congresso não há uma preocupação real com a questão da engenharia orçamentária, fiscal, de ver de onde saem os recursos. Isso é muito típico do Brasil, eu acho. A mentalidade brasileira e a mentalidade dos congressistas são uma mentalidade deficitária. Como se o Estado tivesse milhões de tetas... Por isso os parlamentares não se preocupam com a questão fiscal para iniciar legislação".

Outra explicação é que

"[...] na medida em que a economia e a questão política monopolizam a pauta legislativa do governo, não é fácil para nós [do governo] aprovarmos legislação na área social. Todas as prioridades e todo o empenho do Executivo concentram-se em outras áreas. Questões econômicas e políticas acabam tirando o nosso espaço. Por isso, temos uma dificuldade maior [de passar legislação na área social] do que em outras áreas, porque além de ter as idéias, de propor, de convencer, temos que torcer para que as coisas aconteçam, porque, naturalmente, elas não saem, não acontecem".

Sobre a tendência cada vez mais marcante do papel do Congresso na produção legislativa na área social, dois pontos importantes devem ser enfatizados aqui. O primeiro diz respeito ao estatuto legislativo da emenda constitucional; o segundo, à atuação das comissões permanentes no Congresso Nacional.

Com relação ao primeiro ponto, vale lembrar que, da perspectiva das prerrogativas legislativas que a Constituição de 1988 confere aos dois Poderes (Executivo e Legislativo), a PEC é o instrumento que apresenta o maior custo para a sua aprovação. No Brasil, o quórum de votação (e aprovação) de uma reforma constitucional é de três quintos dos votos; exige-se dois turnos de votação em cada Casa congressual e processo de votação nominal (Constituição de 1988, art. 60). Apesar do alto custo para aprovação de uma PEC, que inclui a formação de grandes coalizões e a criação de consenso político, em um contexto que alguns denominam de "multipartidarismo exacerbado" (Sartori, 1994), o Congresso demonstrou uma capacidade pró-ativa muito maior do que a do Executivo para introduzir e aprovar propostas de emenda constitucional na área da saúde: das quatro PECs apresentadas ao Congresso entre 1985 e 1998, três são de autoria de congressis- 
$\operatorname{tas}^{27}$. Isto significa que o Legislativo brasileiro tem poder efetivo para formar coalizão, criar consenso e aprovar as proposições que julga fundamentais e que, efetivamente, passam pelo trâmite legislativo normal, além de demonstrar força suficiente para formar coalizão e criar consenso sobre questões nacionais importantes (como é o caso daquelas tratadas pelas emendas constitucionais ${ }^{28}$ ).

No que diz respeito ao segundo ponto (atuação das comissões permanentes no Congresso Nacional), vale lembrar que, de acordo com o Regimento Interno da Câmara dos Deputados, as comissões são organizadas em órgãos técnico-legislativos, cuja finalidade é apreciar as proposições submetidas a seu escrutínio. Comissões permanentes constituem a primeira instância deliberativa dos projetos apresentados ao Congresso e, desde a promulgação da Carta de 1988, uma comissão permanente pode aprovar, em caráter terminativo, os projetos sob sua jurisdição - o que significa que eles não precisam passar pelo crivo do plenário para serem transformados em lei (a menos que seja aceito recurso contra a decisão terminativa).

No caso da produção legislativa que nos interessa analisar aqui, é a Comissão de Seguridade Social e Família - CSSF que examina matérias relativas à previdência e assistência social, instituições privadas de saúde, saúde pública e saúde ambiental, além de seguros e previdência privada. Esta comissão é precisamente a que apresenta o maior grau de especialização ocupacional prévia ${ }^{29}$ (associada à área médica), caracterizando-se como uma das comissões permanentes de maior atuação no âmbito congressual (Santos, 1999). Para o período 1995-97, por exemplo, 92,3\% de todos os projetos sancionados na CSSF o foram através de poder terminativo (Silva, 1998 apud Santos, 1999).

O ponto importante a ser destacado é que as comissões permanentes, em geral, e a da Seguridade Social e Família, em particular, têm demonstrado ser um mecanismo importante por meio do qual nossos legisladores têm resgatado sua capacidade "legiferante", aprovando inclusive um número maior de proposições na área social do que os presidentes. Sobre a correlação entre a atuação das comissões permanentes nos trabalhos legislativos e a tendência cada vez mais marcante do papel do Congresso na produção legislativa na área social, vale lembrar que de todo o conjunto de proposições legislativas transformado em lei entre 1995 e 1997, por meio do poder terminativo das co- 
missões, mais de dois terços (66\%) tiveram origem no Legislativo (Tabela 6). Com respeito à área da saúde, um terço da legislação sancionada pelo Congresso, e que teve origem no Poder Legislativo, foi aprovado no âmbito da CSSF.

Tabela 6

Áreas Políticas das Leis Aprovadas por Origem e por Poder Terminativo das Comissões

(1995-1997)

\begin{tabular}{l|c|c|c}
\hline Áreas & Executivo & Legislativo & Total \\
\hline Econômico-Administrativa & 24 & 13 & 37 \\
& $(89 \%)$ & $(25 \%)$ & $(47 \%)$ \\
Social & 3 & 39 & 42 \\
& $(11 \%)$ & $(75 \%)$ & $(53 \%)$ \\
\hline \multirow{2}{*}{ Total } & $\mathbf{2 7}$ & $\mathbf{5 2}$ & $\mathbf{7 9}$ \\
& $\mathbf{( 3 4 \% )}$ & $\mathbf{( 6 6 \% )}$ & $\mathbf{( 1 0 0 \% )}$ \\
\hline
\end{tabular}

Fonte: ProdAsEn apud Santos (1999).

Entretanto, apesar de alguns indicadores de institucionalização, é preciso salientar que o padrão de atuação da CSSF está longe de se constituir em argumento irrefutável sobre a primazia do sistema de comissões do Congresso Nacional em relação às preferências do Poder Executivo. De fato, no Brasil, o Executivo federal dispõe de um conjunto de instrumentos e prerrogativas mediante o qual procede a uma série de limitações da autonomia das comissões legislativas. Em primeiro lugar, juntamente com os líderes partidários, o Poder Executivo desempenha um papel ativo importante no que diz respeito à nomeação dos membros das diferentes comissões. Assim, por se tratar de um sistema marcado pela alta rotatividade (nem sempre voluntária) de seus membros, o Executivo atua visando impedir que a preferência mediana de uma determinada comissão se afaste excessivamente de suas próprias preferências. Além disso, por meio dos pedidos de urgência, o Executivo limita o tempo de apreciação pelos membros das comissões de determinadas proposições, inibindo o trabalho das comissões com preferência mediana muito distante das suas (Pereira e Mueller, 2000) ${ }^{30}$.

Os dados apresentados nesta seção indicam que, apesar de as prerrogativas constitucionais dos presidentes brasileiros garantirem a ascendência do Poder Executivo na produção legal em termos quantita- 
tivos, dados agregados da produção legislativa no período estudado comprovam a força relativa do Congresso Nacional para produzir legislação na área social, em geral, e na da saúde, em particular. Isso significa que, por um lado, enquanto a "força" do Executivo pode ser avaliada pela capacidade que os presidentes tiveram, no período de 1985 a 1998, não só de utilizar suas prerrogativas legislativas constitucionais, mas principalmente de legislar à margem do Congresso (através da reedição de MPs), a intervenção dos legisladores concentrou-se, principalmente, na produção legal sobre os temas gerais de cunho social e sobre aqueles relacionados à estruturação do texto constitucional (projetos de emenda constitucional). De outro lado, os dados exibidos aqui comprovam, também, que a tese de Mayhew é, no caso brasileiro, verdadeira apenas em parte. Se, de fato, parlamentares submetem à apreciação um alto número de proposições legislativas que visam à reeleição, a legislação que eles aprovam contempla também "questões nacionais" importantes. Ademais, no intervalo estudado, o Poder Legislativo no Brasil parece ter demonstrado força suficiente para formar coalizões e criar consenso sobre questões importantes de cunho nacional, especialmente sobre aquelas tratadas nos projetos de emenda constitucional - o que não é pouco, considerando que essas coalizões estão acontecendo em um contexto de "multipartidarismo exacerbado".

\section{PRODUÇÃO LEGISLATIVA, ESTRATÉGIAS DE NEGOCIAÇÃO E RECURSOS POLÍTICOS}

\section{Estratégias de Formulação/Implementação da Lei Orgânica da Saúde}

Esta seção avalia a dinâmica da relação entre presidentes e Congresso Nacional no processo decisório, a partir dos recursos políticos e das estratégias de que estes atores lançam mão para aprovar legislação. Trata da maneira pela qual presidentes se inter-relacionam com o Congresso Nacional em meio ao processo decisório de formulação, aprovação e regulamentação da política de saúde no momento exante à sua implementação. Nossa análise tem por base alguns depoimentos colhidos com representantes do Executivo sobre a produção legal no período examinado.

Já vimos que a LOS, aprovada com veto parcial, constitui a matriz a partir da qual se processou a orientação descentralizadora do SUS. 
De acordo com depoimento do ex-ministro da Saúde do governo Collor, Alceni Guerra, o que se temia no momento da aprovação da LOS era que, caso se abrissem as portas do sistema para a participação popular, "o sistema fosse entregue para setores da extrema-esquerda". Nas palavras de Alceni Guerra:

“[...] o acordo [que resultou na Lei Orgânica da Saúde] foi político. Mas os vetos [sobre os artigos referentes à participação social e ao financiamento do sistema] não foram de caráter político ou de teor técnico-administrativo; foram vetos jurídicos, que foram aconselhados pelo consultor-geral da República diretamente ao presidente" ${ }^{\prime 31}$.

Ademais, ainda segundo Alceni Guerra, a Lei Complementar nํ⒏142 (que tratou de regulamentar as formas de transferência de recursos e a participação da comunidade na gestão do SUS, a partir da criação do Conselho de Saúde ${ }^{32}$ ) resultou de uma tentativa do Poder Executivo e do Congresso Nacional de "redesenhar, numa forma jurídica adequada, a idéia de participação popular que havia sido negociada durante a formulação da LOS", sem se chegar, no entanto, a um consenso. O objetivo principal da Lei Complementar à LOS foi, portanto, integrar a comunidade no Conselho de Saúde e transformar aquela instância em um órgão representativo por excelência, a partir do qual a comunidade deveria gerir o setor de saúde pública. Entretanto, na avaliação do ex-ministro, não foi isso o que aconteceu. Segundo ele,

"O Conselho é um órgão útil, mas que não se aprimorou para o passo seguinte que seria o da gestão comunitária. Na realidade, o Conselho Municipal é útil e indispensável; o modelo continua moderno, mas ele ainda encara a comunidade como apenas um ator a mais - e não como o ator mais importante do sistema. E não é isso. A comunidade é a razão de ser do sistema público de saúde, e a gestão tem de passar para a comunidade. Nós - que ocupamos cargos no Executivo - devemos financiar, controlar e avaliar; a comunidade deve gerir o setor saúde. Isso não se faz da noite para o dia; preparamos o terreno para que, com o passar do tempo, isso aconteça" ${ }^{33}$.

Nessa ótica, não seria correto afirmar que a saída jurídica encontrada pelos formuladores da Lei no 8.142 tenha, de fato, conseguido redesenhar o sistema no sentido do equacionamento da questão da participação popular que o veto parcial ao texto original havia deixado sem solução. Na verdade, os atores responsáveis pela descentralização da política de saúde não estavam preparados para assumir o ingrediente 
Presidentes e Congresso Nacional no Processo Decisório da Política de Saúde...

da incerteza que qualquer processo de democratização institucional acarreta (Przeworski, 1994; 1998). Isto porque a participação popular na gerência do setor da saúde pública não só atemorizava o Executivo - que receava ver o sistema nas mãos de "setores da extrema-esquerda" -, como também outros atores importantes - que temiam que seus interesses fossem prejudicados ao longo do processo. Nesse sentido, as disputas em que o Executivo se envolveu com prestadores de serviço, corporações de servidores públicos e governos estaduais marcaram, de antemão, o caráter das negociações que se travavam fora do âmbito congressual. Com relação aos atores envolvidos nessas negociações, o ex-ministro afirma:

"Confesso que a grande briga que nós travamos naquele momento não foi com o Congresso, mas com o Estado de São Paulo, porque a descentralização e o redesenho da política financeira e de distribuição de valores prejudicavam muito o Estado de São Paulo, que tinha uma força política grande. Daí o fato de termos optado pelo caráter gradativo da descentralização".

"Refiro-me [aqui] não só aos prestadores de serviços, mas também às corporações de servidores, que são muito fortes, por exemplo, no Rio de Janeiro. Era muito difícil o diálogo com os servidores do Rio de Janeiro, assim como era muito difícil o diálogo com os prestadores [de serviços] privados do Estado de São Paulo. Eram dois tipos de atores do sistema que nós tivemos de enfrentar sem estarmos preparados e acho que nós o fizemos com sucesso, apesar de o processo continuar, por assim dizer, com duas mazelas: o excesso de corporativismo, de um lado, e o excesso de voracidade financeira de alguns prestadores [de serviços], de outro".

“Nós nos deparávamos com atores que trabalhavam no cenário há muito tempo e que contavam com todas a virtudes e vícios do sistema" ${ }^{34}$.

Assim, fica claro que o locus de discussão que desenhou o conteúdo da Lei no 8.142 não foi o Congresso Nacional. Essa disputa aconteceu entre representantes do Poder Executivo federal e os prestadores de serviços nos estados da federação, corporações de servidores públicos e representantes dos governos estaduais fora do Congresso Nacional, em um contexto em que a principal característica dos atores envolvidos era a "inexperiência democrática".

“Sabemos que num regime democrático é preciso negociar. Mas nós, enquanto agentes desta transformação, tivemos poucas oportunida- 
des de participação ativa, democrática, durante a nossa juventude, quando vivenciamos o período da ditadura. Não fomos treinados para enfrentar as diferenças. Fomos aprendendo (a negociar) na carne [ao longo do processo] - e estamos ainda aprendendo até hoje. Eu acho que o reparo e os defeitos do sistema sonhado, do sistema perfeito, foram retardados porque havia atores com quem nós tínhamos de negociar e nem sempre tínhamos a habilidade para fazê-lo" ${ }^{\prime 35}$.

Nesse sentido, a estratégia adotada pelos atores envolvidos na formulação/implementação da LOS e da Lei Complementar foi pautada em uma postura que pretendeu ditar (de cima para baixo) o tipo de participação social "aceitável" e o tipo de financiamento "possível". Ademais, a "inexperiência democrática" desses atores foi um ingrediente importante que se tornou um obstáculo à participação social não a penas no processo de discussão da Lei Complementar, mas principalmente no momento posterior à sua aprovação, isto é, no âmbito de gerência do sistema. Não foi por acaso, portanto, que os temas que geraram um impasse nas relações Executivo-Legislativo, no que se refere à política de saúde pública no Brasil democrático, sofreram veto do Executivo.

\section{Recursos Políticos: Distribuição de Cargos, Conversas de Bastidores e Pedidos de Urgência}

Sabemos que a ausência de força partidária que tem caracterizado as diversas administrações no Brasil democrático apresenta, em um contexto de "multipartidarismo exacerbado", conseqüências deletérias para a prática da democracia (Mainwaring, 2001). Uma delas refere-se a um dos problemas enfrentados pelo governo Collor de Mello - administração responsável pela aprovação da LOS -, que foi ter de se defrontar com uma base parlamentar "gelatinosa" ${ }^{36}$ para aprovar a legislação de interesse do Executivo no Congresso Nacional. Sobre este tema, o ex-presidente Collor de Mello assim se pronunciou:

"Fui um presidente que aprovou um pacote de medidas que nem o regime militar com o AI-5 na mão, a caneta e o Congresso fechado ousou fazer; e fiz sem maioria e com a aprovação do Congresso Nacional. A partir dos primeiros projetos aprovados naquele início de governoque é o período de lua-de-mel-, nós tínhamos que buscar os votos em rincões do Congresso a quem a gente nunca esperava ter de apelar. (Como também tivemos recusados votos que nós nunca teríamos ima- 
Presidentes e Congresso Nacional no Processo Decisório da Política de Saúde...

ginado). Então, a conquista por votos se fazia no dia-a-dia. Isso naturalmente não é uma prática que enobrece o jogo político nacional. Mas a questão é saber por que isso acontece? Porque ainda não foi preparada uma reforma política com a preocupação de fortalecer o sistema partidário, de criar esse vínculo entre o filiado e seu partido, e de se fazer no Congresso uma política ou um debate entre ideários de parti$\operatorname{dos}^{37}$ - e não entre defesa de pontos de vista de grupos, corporações ou de setores específicos da vida pública nacional. Hoje não se negocia com partidos, mas sim com bancadas. Existe a bancada ruralista, a bancada das comunicações, a bancada dos bancos, a bancada das estatais, a bancada dos bancários, a bancada dos sindicalistas e assim por diante. Fica muito difícil o Executivo trabalhar num contexto onde a regra do jogo político é o clientelismo." ${ }^{38}$

A exemplo de outros contextos onde o Executivo carece de poderes partidários (Mainwaring e Shugart, 1997; Mainwaring, 2001), reputação profissional ou capacidade de liderança (Neustadt, 1990; Edwards III, 1990), prestígio público (Edwards III, 1976), popularidade ou habilidade política (Edwards III, 1983), para convencer o Congresso a aprovar medidas congruentes com suas preferências, no Brasil, o recurso político da distribuição de patronagem - notadamente a distribuição de posições no governo (Nicolau, 1993), favores pessoais ou empregos (O'Donnell, 1992) - parece ser, na prática, o fator determinante da "força" que alguns estudiosos atribuem ao Executivo brasileiro no processo legislativo (Rodrigues, 1998; 2002).

A esse respeito são ilustrativas algumas das considerações do ex-presidente Fernando Collor quando perguntado a respeito do que faria diferente, caso pudesse voltar atrás:

"Eu dedicaria maior atenção para o Congresso. Na verdade, eu me dediquei muito à administração do país e me esqueci de determinadas conversas [...] de cuidar mais do Congresso [...]. Cuidar mais significa ouvir mais. Ouvir mais [...] significa também distribuir mais cargos. Mas não é só isso. Significa, sobretudo, ter mais disponibilidade de tempo para ouvir." ${ }^{39}$

Já quando perguntado sobre quais os recursos políticos disponíveis para o presidente negociar a aprovação de proposição legislativa no Congresso Nacional, Nelson Jobim respondeu que a distribuição de cargos políticos é um deles, mas que este não é um recurso eficaz porque "quando você escolhe alguém para ocupar um determinado car- 
go, você consegue um amigo e duzentos inimigos". Ademais, segundo o ex-ministro, o presidente não usa esse recurso no sentido de "você vota e eu te dou o cargo". Nas palavras de Jobim: "A questão não é 'Eu só nomeio fulano se você votar na matéria'. Não é isso. $O$ que acontece é que, no momento em que eu nomear alguém que foi indicado por um deputado, eu adquiro com isso um nível de simpatia com relação ao deputado que vai votar." ${ }^{40}$

O curioso é que, dessa ótica, "simpatia" não implica uma situação de toma-lá-dá-cá. Segundo o ex-ministro, "toma-lá-dá-cá não existe". O que se verifica é que o Executivo, quando quer, acaba pautando a agenda do Congresso, indiretamente, mediante a emissão de MPs e pedidos de urgência.

Com relação às medidas provisórias, já discutimos, neste artigo, que uma das conseqüências da reedição sistemática destas é o fato de o Executivo acabar governando e produzindo políticas públicas sem a autorização do Congresso - o que prejudica a transparência do processo legislativo, a relação de reciprocidade entre os Poderes e a responsabilização política. Presidentes que governam com o auxílio da edição/reedição de MPs promovem uma situação que chamamos de accountability negativa, que é tanto produto quanto causa de uma das mais graves fraquezas do sistema político hoje: a incapacidade do Congresso de funcionar como instituição competente não só para modificar as proposições de legislação apresentadas pelo presidente e/ ou impor limites à ação legislativa do Executivo, mas também para propor soluções minimamente eficazes para os problemas do país (Rodrigues, 1998). Em conseqüência dessa situação em que o Executivo legisla "sozinho", cria-se um ambiente fértil para práticas clientelistas e particularistas que desafiam a construção de uma ordem política mais responsável (DaMatta, 1990; Mainwaring, 2001; Nunes, 1997). A Tabela 7 apresenta dados contundentes a respeito do número de MPs reeditadas durante o primeiro mandato de Fernando Henrique.

De acordo com Nelson Jobim:

"O que ocorre com a questão das MPs é o seguinte: o Executivo edita uma medida provisória e o deputado foge de discuti-la porque, apesar de ele saber que aquela medida (que pode ser dura) é necessária, se ele votar favoravelmente, ele terá de ter uma explicação para a sua 
Presidentes e Congresso Nacional no Processo Decisório da Política de Saúde...

Tabela 7

MPs - Edição e Reedição por Administração

(1988-1998)

\begin{tabular}{l|c|c|c|c|c}
\hline Administração & Sarney & Collor & Itamar & FHC & Total \\
\hline MPs originais & 125 & 87 & 141 & 160 & 513 \\
Reeditadas & 22 & 73 & 364 & $2.449^{*}$ & 2.908 \\
Convertidas & 109 & 66 & 118 & 82 & 375 \\
Revogadas & 2 & 5 & 5 & 11 & 23 \\
Sem eficácia & 5 & 5 & 15 & 3 & 28 \\
Rejeitadas & 9 & 11 & - & 1 & 21 \\
Em tramitação & - & - & - & 38 & 38 \\
Editadas & 147 & 160 & 505 & 2.609 & 3.421 \\
\hline
\end{tabular}

Fonte: Couto (2001).

(*) Inclui 699 reedições de governos anteriores.

base eleitoral. Então, o que é que ele faz? Ele simplesmente deixa que a $\mathrm{MP}$, ao se reeditar, ela se consolide." ${ }^{41}$

Quanto aos pedidos de urgência, reconhece-se que tal instituto tem importantes implicações para o esvaziamento do poder terminativo e de um suposto papel informacional desempenhado pelo sistema de comissões no Congresso, já que por meio desse procedimento, com base em algum tipo de articulação com as lideranças partidárias, o Poder Executivo contorna as comissões congressuais de maneira a impedir alterações e apressar a aprovação de proposições de seu interesse. No período 1989-94, a maioria das proposições aprovadas na Câmara dos Deputados tramitou em regime de urgência ou urgência urgentíssima (Figueiredo e Limongi, 1995). Já no período 1995-98, das 805 proposições legislativas promulgadas, 294 (36,5\%) foram objeto de pedido de urgência. Embora a maioria destes tenha incidido sobre proposições iniciadas pelo Executivo - $237(80,6 \%)$-, é significativo que a maior parte dos pedidos de urgência $(70,4 \%)$ tenha sido iniciativa do Legislativo (Pereira e Mueller, 2000).

A relativa centralização do processo de tomada de decisão no âmbito congressual é outro elemento fundamental em uma análise das relações Executivo/Legislativo para efeito da apresentação e aprovação de proposições legislativas no Congresso brasileiro. Deve-se lembrar que entre os meios políticos de que o Executivo pode lançar mão para 
aprovar legislação estão as "conversas de bastidores". Normalmente, a Presidência utiliza-se deste recurso previamente ao envio de projetos "prontos" (já negociados) ao Congresso. Estas negociações ocorrem, segundo Nelson Jobim, com os líderes do governo e os presidentes das Câmaras Alta e Baixa. Afinal, "quem faz a pauta dentro do Congresso é o presidente da Câmara e o presidente do Senado. Por isso é preciso que haja uma articulação muito forte entre o Executivo (o presidente da República) e os presidentes das duas Casas" ${ }^{\prime 2}$.

Sobre o argumento de que, freqüentemente, representantes do Poder Executivo lançam mão do expediente de "conversas de bastidores" como forma de "negociar" determinada proposição legislativa antes que seja enviada ao plenário, Nelson Jobim afirma:

"Quando eu mando um projeto para o Congresso que seja minha área (de atuação), ou no caso de o presidente enviar um projeto em que eu sou o responsável, primeiro eu tento montar uma articulação com os líderes do governo. Algumas vezes, eu converso diretamente com o presidente da comissão, para acertar com ele quem será o relator da matéria. Quando a matéria é urgente e relevante, o nome do relator já sai acertado do Executivo. E este relator servirá como ponte entre o ministério e o plenário... [mas] este é o tipo de capital político que não se pode usar sempre, senão você desgasta" ${ }^{43}$.

\section{CONSIDERAÇÕES FINAIS}

Este artigo focalizou a dinâmica da relação Executivo-Legislativo no processo decisório da política de saúde no período entre 1985 e 1998. Nosso objetivo foi relativizar a capacidade "legiferante" dos presidentes brasileiros na área de saúde e demonstrar que o Executivo é "forte" não só porque possui amplos poderes constitucionais e regimentais para produzir legislação e acelerar o trâmite do processo legislativo, mas, principalmente, porque legisla à margem do Congresso. Ademais, no Brasil, os presidentes não têm demonstrado força suficiente para aprimorar uma relação de reciprocidade entre os Poderes, para governar com o Congresso Nacional, para ampliar os benefícios sociais, nem para dar a última palavra no processo decisório da política de saúde.

Demonstramos, também, que o uso que os presidentes fizeram do instrumento da reedição de medidas provisórias facilitou o "atraves- 
samento" da instância representativa mais importante do regime democrático - o Congresso Nacional -, ao invés de contribuir para o aprimoramento das instituições democráticas. Além disso, em um contexto de "multipartidarismo exacerbado", a utilização de recursos políticos como distribuição de patronagem para formar coalizões ad hoc e negociação de proposições legislativas fora do âmbito congressual acabou, de fato, comprometendo a capacidade política do Poder Executivo, que não demonstrou força suficiente para realizar as reformas necessárias e que visam à ampliação dos benefícios sociais. Se a construção de um Sistema Único de Saúde está entre as medidas de reforma mais bem-sucedidas na área social no período pós-transição, do ponto de vista de sua extensão não se pode dizer o mesmo com relação à correção de algumas distorções herdadas de nosso passado - como a exclusão social e a forte centralização decisória na área das políticas sociais. O impacto negativo desses fatores no regime democrático parece evidente.

Em uma palavra, a reformulação do conteúdo da política de saúde -a partir de uma efetiva participação social nos Conselhos de Saúde, por exemplo - e a redefinição das relações de poder cristalizadas no interior do sistema parecem não ter avançado muito ao longo do período aqui analisado. As razões disso nos remetem não só ao fato de a política de saúde esbarrar nas limitações de ordem estrutural (leia-se escassez de recursos), mas também à falta de uma visão democratizante dos atores políticos que têm a palavra no processo decisório.

Ademais, o artigo apontou o uso indiscriminado que os presidentes fizeram do recurso da edição/reedição de MPs (antes de sua regulamentação pelo Congresso) como um fator limitador importante do espaço de atuação dos congressistas para lapidar a legislação que o Executivo iniciou na área da saúde entre 1985-98. Disso resultou uma situação em que o Executivo parece ter produzido, praticamente sozinho, parte significativa da legislação na área da saúde durante o período em tela. Dados apresentados na Tabela 1, por exemplo, mostram que das 82 MPs que o Executivo apresentou ao Congresso nessa área, apenas seis foram transformadas em lei.

Outro elemento importante que acaba restringindo o papel do Legislativo no processo de discussão/aprovação de leis é o recurso constitucional do veto presidencial. Isso quer dizer que toda vez que os parlamentares modificam uma proposição apresentada pelo Executivo 
no Congresso, o presidente pode aprovar legislação desconsiderando as modificações, fazendo uso do veto parcial. Sobre o tema da utilização do veto parcial para desfigurar propostas do Legislativo, o exemplo discutido neste artigo foi o da Lei (nº 8.080) Orgânica da Saúde, sancionada com veto presidencial em artigos fundamentais como o relativo à participação da comunidade na gestão do Sistema Único de Saúde e ao financiamento do sistema.

Por fim, um terceiro fator importante que limitou o papel do Congresso no desenho da legislação produzida na área da saúde refere-se às proposições legislativas de autoria do Executivo que chegam "prontas" ao Congresso Nacional. Essas peças legislativas vão a plenário após terem alcançado um certo tipo de acordo ou passado por algum tipo de discussão, ambos, de maneira geral, restritos às lideranças (Novaes, 1994). No caso da saúde, em particular, o exemplo apontado aqui (Lei n 8.142, complementar à LOS, que dispõe sobre a participação da comunidade na gestão do SUS e as condições e formas de transferência de recursos) pretendeu demonstrar que a discussão que desenhou o conteúdo da LOS não passou nem ao menos pelo crivo das lideranças congressuais. Segundo o ex-ministro da Saúde Alceni Guerra, a discussão sobre a Lei no 8.142 aconteceu fora do Congresso Nacional e dela participaram representantes do Poder Executivo federal, prestadores de serviços nos estados, corporações de servidores públicos e representantes dos governos estaduais.

Assim, nos três casos (uso indiscriminado de MPs, utilização do veto parcial para desfigurar as modificações propostas pelo Poder Legislativo e envio de peças legislativas para plenário que estão "prontas" para votação) ocorre o fenômeno de "atravessamento" do Congresso Nacional por parte do Poder Executivo.

De outro lado, este artigo salientou, igualmente, o fato de que o Congresso brasileiro tem demonstrado força suficiente não apenas para organizar discussões entre experts na área de saúde pública no interior da Comissão de Seguridade Social e Família, como também para aprovar um número crescente de projetos de lei na área social (Tabela 5) e sancionar um número maior de projetos de emenda constitucional do que o Executivo na área da saúde. Entre as propostas de emenda à Constituição (PECs) que tiveram origem no Legislativo, no período analisado aqui, estão: a PEC 40/1995 (transformada em EC 12/1996), que dispõe sobre financiamento das ações e serviços de 
saúde; a PEC 34 / 1998 (EC 21 / 1999), que altera o artigo 74 das disposições constitucionais e trata do custeio da área da saúde; e a PEC 28/1996 (EC 26/2000), que altera o artigo 6º da Constituição de 1988, colocando moradia, educação e saúde no rol dos direitos sociais. $\mathrm{O}$ Poder Executivo foi autor de apenas uma proposta de emenda constitucional na área social (PEC 33/1995, transformada em EC 20/1998), que adota critério diferenciado para a concessão de aposentadoria nos casos de atividades que prejudiquem a saúde.

Apesar dos dispositivos legais, dos recursos políticos e do poder de decreto com força de lei (edição/reedição de MPs) de que os presidentes brasileiros dispõem para legislar, o Congresso Nacional demonstrou no período examinado (1985-98) força suficiente para dominar a produção legislativa na área social. Assim, podemos concluir que os parlamentares brasileiros têm, de fato, incrementado sua capacidade "legiferante" na área social, em geral, e na da saúde, em particular, ao mesmo tempo que a preponderância do Executivo na produção de leis nessa área deve ser relativizada. Da força que é atribuída ao Executivo brasileiro pelo uso que os presidentes têm feito do poder constitucional para legislar através de MPs (assim como a prática da reedição sistemática de MPs) resulta uma situação que não contribui para o aprimoramento da relação de reciprocidade entre os Poderes. Pelo contrário, no período em questão, os presidentes demonstraram poder suficiente para baixar MPs com força de lei, mas não tiveram força bastante para sancioná-las. Em função dos dados apresentados neste artigo, não é exagero concluir que, dada a natureza das relações Legislativo-Executivo no período analisado, o Legislativo brasileiro tende a se afirmar como o principal legislador do país na área de saúde.

(Recebido para publicação em abril de 2002) 


\section{NOTAS}

1. Melo (1990) qualifica o novo padrão de políticas públicas na área social implementado a partir do governo Geisel como "reformista conservador", em virtude de tratar-se de uma estratégia que buscava uma reorientação do processo de crescimento econômico, no sentido da incorporação controlada de novos atores sociais a alguns dos benefícios do desenvolvimento. Sem qualquer alteração substancial nas políticas salarial e tributária, procurava-se adotar medidas voltadas para a desconcentração da renda a partir da oferta de bens e serviços sociais, ao mesmo tempo que se conservavam inalteradas as posições ex ante dos principais atores do conflito distributivo. Tudo isso tendo como pressuposto a manutenção do crescimento da economia.

2. Sem que se tenha estabelecido constitucionalmente uma nítida divisão dos encargos sociais entre municípios, estados e União.

3. A classificação das federações democráticas ao longo do continuum demos constraining é feita por Stepan com base em quatro variáveis: 1) o grau de sobre-representação do Senado; 2) a abrangência das políticas formuladas pelo Senado; 3) a extensão das prerrogativas atribuídas pela Constituição às unidades da federação para efeito de elaboração de políticas; 4) o grau de nacionalização das orientações e sistemas de incentivos do sistema partidário.

4. Enquanto a noção de descentralização pela oferta envolve um processo de implementação de medidas de cima para baixo, a noção de descentralização pela demanda remete àqueles processos de descentralização impulsionados de baixo para cima, em virtude de pressões de unidades subnacionais em busca de mais recursos e de maior autonomia em face do poder central.

5. Para uma descrição do Instituto de Aposentadoria e Pensões dos Industriários IAPI como uma self-directing agency, cujos quadros burocráticos estão envolvidos em uma política de defesa institucional baseada em uma concepção de seguro social dos benefícios previdenciários em bases atuariais, ver Hochman (1992).

6. Segundo Arretche (1999), as diferenças observadas no processo de descentralização das diferentes políticas sociais decorrem das respostas de estados e municípios às estruturas de incentivos para que assumam responsabilidades em cada área de política, e da forma pela qual as variáveis estruturais e institucionais relevantes são processadas no âmbito da tomada de decisões das administrações locais e intermediárias relativas à assunção de determinadas responsabilidades.

7. A expressão policy window designa uma "janela de oportunidades", uma determinada conjuntura em que o equacionamento de certos problemas, a formulação de propostas de resolução desses problemas e a ocorrência de mudanças no ambiente político propiciam a introdução de mudanças na agenda pública pela conjunção de fluxos de eventos independentes.

8. Além de documentação oficial - Carta de 1988, NOBs (1/91, 1/93, 1/96), LOS (Lei no 8.080/90), Lei Complementar no 8.142/90, decreto presidencial no 99.438 e PECs (33/1995, 40/1995, 28/1996, 34/1998) -, outras fontes foram utilizadas aqui: Szazi e Prado (1999) e Silva et alii (1999). 
9. A legalidade e/ou constitucionalidade da atividade normativa autônoma ou reguladora do Poder Executivo é controlada pelo Judiciário. Por isso, os decretos da Presidência, portarias de ministérios e resoluções de órgãos ligados ao Executivo, que mencionamos aqui, não passaram pelo crivo do Congresso, mas do Supremo Tribunal Federal. Sobre este tema, ver Arantes e Kerche (1999:37).

10. A Conferência de Saúde pode ser convocada pelo Executivo municipal ou pelo Conselho de Saúde a cada quatro anos.

11. Acadêmicos que restringem a definição de "força" presidencial aos poderes constitucionais do Executivo aventam a hipótese de que, no Brasil, os presidentes são muito fortes não só porque contam com "a forma mais austera de lawmaking presidencial do mundo" (Carey e Shugart, 1992:151), que é o poder de baixar medidas provisórias, mas, principalmente, porque esta ferramenta legislativa propicia uma situação na qual a Presidência acaba por legislar quase que independentemente do Congresso Nacional (Figueiredo e Limongi, 1995; 1999).

12. Sobre a emenda votada em segundo turno no Senado para regulamentar o estatuto da MP que, entre outras medidas, proíbe a reedição irrestrita, ver Folha de S.Paulo, 12/9/2001, "Emenda sobre MPs começa a vigorar hoje", p. A-39.

13. Tudo isso sem mencionar aquelas policy-areas como matérias orçamentárias (art. 165) e outras (art. 84) em que o Executivo brasileiro detém direito exclusivo para legislar. Sobre este tema, ver Novaes (1994), Figueiredo (1995), Samuels (1998). As regras de disputa estão explicitadas nos regimentos internos da Câmara e do Senado, assim como na Carta de 1988. Sobre o estatuto do veto parcial, ver também Mezey (1989), Watson (1993), Immergut (1996), Tsebelis (1997).

14. Com relação ao pedido de urgência (garantido pelo art. 64 da Constituição de 1988 e arts. 151, 157, 158 e 204 do Regimento Interno da Câmara dos Deputados), estudos sobre a organização interna dos trabalhos legislativos da Câmara indicam que um resultado dessa regra é a preponderância do Executivo na função legislativa (Figueiredo et alii, 2000). Dados levantados pelo CeBraP junto ao ProdASEN mostram, por exemplo, que, no período entre 1989 e 1994, a maioria dos projetos (55\%) votados na Câmara dos Deputados tramitou em regime de urgência urgentíssima.

15. Por capacidade pró-ativa entendemos a capacidade que os presidentes (ou membros do Congresso) têm para iniciar legislação e/ou introduzir um novo status quo através de legislação (Carey e Shugart, 1992).

16. Um exemplo desse tipo de ocorrência foi a MP editada no governo Fernando Henrique Cardoso para regulamentar as Leis no 8.019 e 8.212 sobre os repasses do Fundo de Amparo ao Trabalhador-FAT, que teve força de lei por um período de quase três anos (foi reeditada 34 vezes) e perdeu eficácia, ou seja, deixou de ser reeditada pelo Executivo - sem nunca ter passado pelo plenário.

17. Ofícios referem-se àquelas medidas que autorizam os Executivos estaduais a contrair financiamento na área da saúde. Quando aprovados, os ofícios são transformados em projetos de resolução do Senado Federal.

18. Sobre este ponto, basta lembrar que, no dia anterior à promulgação da emenda constitucional que regulamentou o instituto da medida provisória, o Executivo editou, de uma só vez, um pacote composto por dez MPs com validade indetermi- 
nada, isto é, o presidente nem precisará reeditá-las (Folha de S. Paulo, 6/9/2001, p. A-8 e 12/9/2001, p. A-39).

19. Segundo os termos aprovados em fevereiro de 1989 pela Resolução no 1 , caso o comitê especialmente formado por membros da Câmara e do Senado para discutir o conteúdo de uma determinada medida provisória decida pela sua mudança, essa modificação pressupõe que esta MP seja, automaticamente, transformada em um projeto de lei de conversão-PLV adquirindo, inclusive, um novo número. Um PLV é considerado proposição legislativa de iniciativa do Congresso Nacional.

20. Por poder reativo do Congresso, entendemos a capacidade que os parlamentares têm para bloquear e/ou modificar legislação que o Executivo introduz via MP. O objetivo desta intervenção é manter o status quo contra a tentativa do Executivo para mudá-lo por decreto (Carey e Shugart, 1992).

21. Entendemos por poder reativo do Executivo sua capacidade para intervir na ponta do processo legislativo, vetando a legislação que o Congresso aprova. O objetivo desta intervenção é manter o status quo contra a tentativa da maioria do Congresso para mudá-lo (Carey e Shugart, 1992).

22. Em outro lugar, Jobim nomeou esses projetos como "projetos de estatística" (Jobim, 1994).

23. Entrevista concedida à Marta M. Assumpção Rodrigues (Notre Dame, IN, 11/12/1996).

24. A diferença entre o número de projetos de lei apresentados e o número de leis aprovadas refere-se aos projetos arquivados (566), prejudicados (104), tramitando nas comissões (85), anexados (75), retirados pelo autor (26), devolvidos (14), além daqueles que foram rejeitados, remetidos para a Câmara ou para o Senado, vetados totalmente (sem que estes vetos tenham sido derrubados), ou que estão prontos para ordem do dia.

25. As leis sociais compreendem os programas sociais stricto sensu em áreas como saúde, educação, previdência, habitação e trabalho, e aquelas que regulam uma gama mais ampla de atividades sociais (como profissões, justiça, direitos civis, meio ambiente etc.).

26. Entrevista concedida à Marta M. Assumpção Rodrigues (Notre Dame, IN, 1/10/ 1995).

27. Senadores Antonio Carlos Valadares (PP-SE) - PEC 40; Mauro Miranda (PMDB-GO) - PEC 28; Elcio Álvares (PFL-ES) - PEC 34.

28. A PEC nº 40/1995 transformada em Emenda Constitucional - EC no 12/1996 (que dispõe sobre financiamento das ações e serviços de saúde); a PEC nº 34 / 1998 transformada em EC nํ21/1999 (que altera o artigo 74 das Disposições Constitucionais Transitórias e trata do custeio da área da saúde) e a PEC no 28/1996 transformada em EC nํ26/2000 (que altera o artigo 6으 da Constituição de 1988, colocando moradia, educação e saúde no rol dos direitos sociais) tiveram origem no Poder Legislativo. A PEC n 33/1995 transformada em EC no 20/1998 (que modifica o sistema de previdência) é de autoria do Poder Executivo.

29. Ao lado da Comissão de Agricultura e Política Rural. 
Presidentes e Congresso Nacional no Processo Decisório da Política de Saúde...

30. Segundo informações obtidas junto a Bernardo Mueller, as preferências medianas dos membros da CSSF durante o período 1995-98 permitem-nos afirmar que essa comissão é marcada por um alto nível de lealdade ao Executivo.

31. Entrevista concedida à Marta M. Assumpção Rodrigues (Pato Branco, SC, $1 / 10 / 1999)$.

32. OConselho de Saúde tem representação paritária (governo municipal, prestadores de serviços e representantes da sociedade civil organizada).

33. Entrevista concedida à Marta M. Assumpção Rodrigues (Pato Branco, SC, $1 / 10 / 1999)$.

34. Idem.

35. Idem.

36. Chamamos de base parlamentar "gelatinosa" aquelas coalizões ad hoc que se compõem no Congresso de acordo com o tema de cada proposição legislativa a ser apreciada. Sobre o assunto, ver Rodrigues (1998).

37. Em entrevista concedida por Nelson Jobim à Marta M. Assumpção Rodrigues (Notre Dame, IL, 16/11/1996) foi feito um comentário semelhante: "o aprimoramento da nossa política vai depender de uma reforma política que mude as regras do jogo eleitoral, para então fazer com que a fidelidade partidária e o programa partidário sejam algo que produza votos".

38. Entrevista concedida à Marta M. Assumpção Rodrigues (Miami, FL, 14/10/1996).

39. Idem.

40. Entrevista concedida à Marta M. Assumpção Rodrigues (Notre Dame, IL/11/12/1996).

41. Idem.

42. Idem.

43. Idem. 


\section{REFERÊNCIAS BIBLIOGRÁFICAS}

ABRUCIO, Fernando Luiz. (1994), "Os Barões da Federação". Lua Nova, no 33, pp. 165-183.

(2001), "A Reconstrução das Funções Governamentais no Federalismo Brasileiro", in W. Hofmeister e J. M. B. Carneiro (orgs.), Federalismo na Alemanha e no Brasil. São Paulo, Konrad Adenauer, pp. 95-105.

e SAMUELS, David. (1997), "A Nova Política dos Governadores". Lua Nova, nำ 40/41, pp. 137-166.

AFONSO, José Roberto Rodrigues e LOBO, Thereza. (1996), “Descentralização Fiscal e Participação em Experiências Democráticas Retardatárias". Planejamento e Políticas Públicas, no 14, pp. 3-32.

ALMEIDA, Maria Hermínia Tavares de. (1995), "Federalismo e Políticas Sociais". Revista Brasileira de Ciências Sociais, ano 10, no28, pp. 88-108.

ARANTES, Rogério Bastos e KERCHE, Fábio. (1999), “Judiciário e Democracia no Brasil". Novos Estudos CEBRAP, no 54, pp. 27-41.

ARRETCHE, Marta T. S. (1996), "Mitos da Descentralização: Mais Democracia e Eficiência nas Políticas Públicas?". Revista Brasileira de Ciências Sociais, ano 11, no 31, pp. 44-66.

. (1998), A Estratégia de Municipalização da Política Nacional de Atenção à Saúde. Relatório (primeira etapa) do Projeto de Pesquisa A Efetividade do Gerenciamento e do Perfil do Gasto nos Municípios Habilitados para a Gestão Semiplena no Período 1994-1997. NEPP/UnicAmP e Ministério da Saúde, Campinas, SP.

. (1999), "Políticas Sociais no Brasil: Descentralização em um Estado Federativo". Revista Brasileira de Ciências Sociais, vol. 14, no 40, pp. 111-141.

AUGUSTO, Maria Helena Oliva e COSTA, Olavo Viana. (2000), “Entre o Público e o Privado - A Saúde Hoje no Brasil”. Tempo Social, vol. 11, no 2, pp. 199-217.

CAREY, John M. e SHUGART, Matthew S. (1992), Presidents and Assemblies: Constitutional Design and Electoral Dynamics. New York, Cambridge University Press. . (1998), “Poder de Decreto - Chamando os Tanques ou Usando a Caneta?". Revista Brasileira de Ciências Sociais, vol. 13, no 37, pp. 149-184.

COSTA, Nilson do Rosário. (1996), "Inovação Política, Distributivismo e Crise: A Política de Saúde nos Anos 80 e 90". Dados, vol. 39, no 3, pp. 479-512.

COUTO, Cláudio Gonçalves. (2001), "A Regulamentação das Medidas Provisórias: Algo Além da Delegação". Conjuntura Política, no27 (http:/ / cevep.ufmg.br/bacp).

DAMATTA, Roberto. (1990), Carnavais, Malandros e Heróis. Para uma Sociologia do Dilema Brasileiro (5- ed.). Rio de Janeiro, Editora Guanabara.

DRAIBE, Sônia Míriam. (1994), "As Políticas Sociais do Regime Militar Brasileiro: 1964-85”, in G. A. Soares e M. C. D’A Araújo (orgs.), 21 Anos de Regime Militar: Balanço e Perspectivas. Rio de Janeiro, Fundação Getulio Vargas Editora, pp. 271-309. 


\section{Presidentes e Congresso Nacional no Processo Decisório da Política de Saúde...}

(1995), “Repensando a Política Social: Dos Anos 80 ao Início dos 90", in L. Sola e L. M. Paulani (orgs.), Lições da Década de 80. São Paulo, EdusP, pp. 201-221.

(1997), “A Política Social na América Latina: O que Ensinam as Experiências Recentes de Reformas?", in E. Diniz e S. Azevedo (orgs.), Reforma do Estado e Democracia no Brasil. Brasília, ENAP/UnB, pp. 213-258.

_. CASTRO, Maria Helena Guimarães de e AZEREDO, Beatriz. (1991), O Sistema de Proteção Social no Brasil. Campinas, SP, NEPP/UnICAMP.

EDWARDS III, George. (1976), “Presidential Influence in the House: Presidential Prestige as a Source of Power". American Political Science Review, vol. 70, nำ1, pp. 101-113.

. (1983), The Public Presidency. The Pursuit of Popular Support. New York, St. Martin's Press.

. (1990), At the Margins. Presidential Leadership of Congress. New Haven, Yale University Press.

ESPING-ANDERSEN, Gosta. (1990), The Three Worlds of Welfare Capitalism. Princeton, Princeton University Press.

FIGUEIREDO, Argelina. (1995), “O Papel do Executivo na Produção Legislativa (1989-1992)”, in G. Villas Bôas e A. Gonçalves (orgs.), O Brasil na Virada do Século. O Debate dos Cientistas Políticos. Rio de Janeiro, Relume-Dumará, pp. 275-283.

e LIMONGI, Fernando. (1995), "Poderes Legislativos e o Poder do Congresso". Monitor Público, vol. 5, no 2, pp. 33-37.

. (1999), Executivo e Legislativo na Nova Ordem Constitucional de 1998. São Paulo, Fundação Getulio Vargas Editora.

_ e VALENTE, Ana Luzia. (2000), “Governabilidade e Concentração de Poder Institucional - O Governo FHC". Tempo Social, vol. 11, nº 2, pp. 49-62.

GOMES, Gustavo Maia e MACDOWELL, Maria Cristina. (2000), "Descentralização Política, Federalismo Fiscal e Criação de Municípios: O que É Mau para o Econômico nem Sempre É Bom para o Social". Texto para Discussão, no 706, IPEA.

HOCHMAN, Gilberto. (1992), “Lógica da Ação Burocrática e Políticas Públicas - O Caso dos Cardeais da Previdência Social", in AnPocs, Ciências Sociais Hoje. Rio de Janeiro, Rio Fundo/AnPOCS, pp. 102-138.

IMMERGUT, Ellen M. (1996), “As Regras do Jogo: A Lógica da Política de Saúde na França, na Suíça e na Suécia". Revista Brasileira de Ciências Sociais, ano 11, no 30, pp. 139-166.

JOBIM, Nelson. (1994), "O Colégio de Líderes e a Câmara dos Deputados". Cadernos de Pesquisa Cebrap, no 3, pp. 37-59.

KINGDON, John W. (1993), “How Do Issues Get on Public Policy Agendas?”, in W. J. Wilson (ed.), Sociology and the Public Policy Agenda. London, Sage, pp. 40-50.

KUGELMAS, Eduardo. (2001), "A Evolução Recente do Regime Federativo no Brasil", in W. Hofmeister e J. M. B. Carneiro (orgs.), Federalismo na Alemanha e no Brasil. São Paulo, Konrad Adenauer, pp. 29-49. 
e SOLA, Lourdes. (2000), “Re-centralização/Descentralização: Dinâmica do Regime Federativo no Brasil dos Anos 90". Tempo Social, vol. 11, nํ2, pp. 63-81.

MAINWARING, Scott P. (2001), Sistemas Partidários em Novas Democracias: O Caso do Brasil. Rio de Janeiro, Fundação Getulio Vargas Editora/Mercado Aberto. e SHUGART, Matthew S. (1997), Presidentialism and Democracy in Latin America. Cambridge, Cambridge University Press.

MALLOY, James. (1986), A Política de Previdência Social no Brasil. Rio de Janeiro, Graal.

MAYHEW, David R. (1974), Congress: The Electoral Connection. New Haven, Yale University Press.

MELO, Marcus André. (1990), “A Formação de Políticas Públicas e a Transição Democrática: O Caso da Política Social”. Dados, vol. 33, n 3, pp. 443-470. . (1998), “As Sete Vidas da Agenda Pública Brasileira", in E. M. Rico (org.), Avaliação de Políticas Sociais: Uma Questão em Debate. São Paulo, Cortez, pp. 11-28.

. (1999), "Estado, Governo e Políticas Públicas", in O Que Ler na Ciência Social Brasileira (1970-1995) (volume III, Ciência Política). São Paulo, Sumaré/AnPOCs, pp. 59-99.

MEZEY, Michael L. (1989), Congress, the President, and Public Policy. Boulder, Co., Westview Press.

MORGENSTERN, Scott. (1996), The Electoral Connection and the Legislative Process in Latin America: Parties, Factions, and Alliances in Theory and Practice. Ph.D. Dissertation, University of California, San Diego.

NEUSTADT, Richard E. (1990), Presidential Power and the Modern Presidencies: The Politics of Leadership from Roosevelt to Reagan. New York, Maxwell MacMillan.

NICOLAU, Jairo. (1993), Sistema Eleitoral e Reforma Política. Rio de Janeiro, Foglio.

NOVAES, Carlos Alberto Marques. (1994), “Dinâmica Institucional da Representação. Individualismo e Partidos na Câmara dos Deputados". Novos Estudos CEBRAP, nํ38, pp. 99-147.

NUNES, Edson de Oliveira. (1997), A Gramática Política do Brasil: Clientelismo e Insulamento Burocrático. Rio de Janeiro, Zahar.

O'DONNELL, Guillermo. (1992), "Transitions, Continuities, and Paradoxes", in S. Mainwaring, G. O'Donnell e J. S. Valenzuela (eds.), Issues in Democratic Consolidation. The New South American Democracies in Comparative Perspective. Notre Dame, University of Notre Dame Press, pp. 17-56.

PEREIRA, Carlos e MUELLER, Bernardo. (2000), “Uma Teoria da Preponderância do Poder Executivo. O Sistema de Comissões no Legislativo Brasileiro". Revista Brasileira de Ciências Sociais, vol. 15, no 43, pp. 45-67.

PINHEIRO, Vinícius C. (1995), “Modelos de Desenvolvimento e Políticas Sociais na América Latina em uma Perspectiva Histórica". Planejamento e Políticas Públicas, no 12, pp. 63-88. 
Presidentes e Congresso Nacional no Processo Decisório da Política de Saúde...

POWER, Timothy. (1998), "The Pen Is Mightier than the Congress: Presidential Decree Power in Brazil", in M. S. Shugart e J. M. Carey (eds.), Executive Decree Authority. Cambridge, Cambridge University Press, pp. 197-232.

PRZEWORSKI, Adam. (1994), Democracia e Mercado no Leste Europeu e na América Latina. Rio de Janeiro, Relume-Dumará.

. (1998), O Estado e o Cidadão. Trabalho apresentado no seminário internacional Sociedade e Reforma do Estado. São Paulo, 26-28 de março.

RODRIGUES, Marta M. Assumpção. (1998), “Strong” Presidents, “Weak” Congresses? A Review of the Executive-Legislative Relations in Brazil, 1985-1996. Ph.D. Dissertation, University of Notre Dame, Notre Dame.

. (1999), A Efetividade do Gerenciamento em Cinco Municípios: Porto Alegre (RS), Balneário Camburiú e Lages (SC), Pato Branco e Concórdia (PR). Relatório (segunda etapa) do Projeto de Pesquisa A Efetividade do Gerenciamento e do Perfil do Gasto nos Municípios Habilitados para a Gestão Semiplena no Período 1994-1997. NEPP/UNICAMP e Ministério da Saúde, Campinas, SP.

. (2002), “Accountability e Poder Constitucional do Executivo Brasileiro: Decreto, Medida Provisória e Tramitação de Urgência”. Teoria e Sociedade, no 9, pp. 158-199.

SALM, Cláudio e COUTINHO, Maurício C. (1986), "Previdência Social”, in E. Bacha e H. S. Klein (orgs.), A Transição Incompleta. Rio de Janeiro, Paz e Terra, vol. 2, pp. 211-243.

SAMUELS, David J. (1998), Careerism and its Consequences: Federalism, Elections, and Policy-Making in Brazil. Ph.D. Dissertation, University of California, San Diego.

SANTOS, Fabiano. (1999), Partidos Políticos e Comissões Permanentes na Câmara dos Deputados: 1995 a 1998. Trabalho apresentado no seminário Desarrollo Político Comparado de Argentina y Brasil. Buenos Aires, 25-26 de março.

SARTORI, Giovanni. (1994), Comparative Constitutional Engineering: An Inquiry into Structures, Incentives and Outcomes. New York, New York University Press.

SCHMITT, Rogério Augusto. (1995), "A Agenda da Reforma Política no Brasil”. Cadernos de Conjuntura, no 52 - Relações Executivo-Legislativo: Conflito, Consenso e a Nova Dinâmica Congressual, pp. 15-19.

SCHMITTER, Philippe. (1974), "Still the Century of Corporatism?", in F. B. Pike e T. Strich (eds.), The New Corporatism: Social-Political Structures in the Iberian World. Notre Dame, University of Notre Dame Press, pp. 85-131.

SERRA, José e AFONSO, José Roberto Rodrigues. (1999), "Federalismo Fiscal à Brasileira: Algumas Reflexões". Revista do BNDES, vol. 6, nํ12, pp. 3-30.

SILVA, Igor Gervásio Gouvêa da. (1998), O Poder Legislativo Reage: A Importância das Comissões Permanentes no Processo Decisório da Câmara dos Deputados. Dissertação de Mestrado, Universidade Federal Fluminense - UFF, Niterói, RJ.

SILVA, Pedro Luiz Barros, RIBEIRO, José Mendes e COSTA, Nilson do Rosário. (1999), "A Descentralização do Sistema de Saúde no Brasil". Revista do Serviço Público, vol. 50, no 3, pp. 33-56. 
STEPAN, Alfred. (1999), "Para uma Nova Análise Comparativa do Federalismo e da Democracia: Federações que Restringem ou Ampliam o Poder do Demos". Dados, vol. 42, no 2, pp. 197-252.

SZAZI, Eduardo e PRADO, Maurício. (1999), O Regime Legal do Sistema Único de Saúde. Uma Avaliação do Ordenamento e da Evolução Legislativa de Descentralização da Saúde Pública no Brasil. Relatório de Consultoria Jurídica preparado para o Projeto de Pesquisa A Efetividade do Gerenciamento e do Perfil do Gasto nos Municípios Habilitados para a Gestão Semiplena no Período 1994-1997. NEPP/Unicamp e Ministério da Saúde, Campinas, SP.

TITMUSS, Richard. (1974), Social Policy. An Introduction. London, George Allen \& Unwin.

TORRE, Juan Carlos. (1987), "A Transição na América Latina", in Anais do Simpósio: A Transição Política: Necessidade e Limites da Negociação. São Paulo, Universidade de São Paulo - USP, pp. 98-103.

(1993), “América Latina: O Governo da Democracia em Tempos Difíceis", in L. Sola (org.), Estado, Mercado e Democracia. Rio de Janeiro, Paz e Terra, pp. 127-193.

TSEBELIS, George. (1997), “Processo Decisório em Sistemas Políticos: Veto Players no Presidencialismo, Parlamentarismo, Multicameralismo e Pluripartidarismo". Revista Brasileira de Ciências Sociais, vol. 12, no 34, pp. 89-117.

WATSON, Richard A. (1993), Presidential Vetoes and Public Policy. Lawrence, Kansas University Press.

\section{ABSTRACT \\ The Presidents and the National Congress in the Decision-Making Process of Health Policies in Democratic Brazil (1985-1998)}

The article assesses the dynamics of the decision-making process of health policy in Brazil from the viewpoint of Executive-Legislative relations. It examines institutional mechanisms, negotiation strategies and political resources available to introduce, amend and regulate laws in this social arena. It shows that congressional capacity to refine laws proposed by the Executive branch is still limited (particularly due to both the Medidas Provisórias (Provisional Measure) and veto power of the Executive), but concludes that the legislative power of Presidents in the area of health must be tempered. After all, during the period under analysis (1985-1998), Congress displayed enough power to approve a growing number of bills and constitutional amendments in the area of health - significantly greater than the Executive's.

Keywords: health policy; Executive and Legislative relations; decision-making process; democratic Brazil 


\section{RÉSUMÉ}

Les Présidents et le Congrès National dans le Processus Décisionnel de la Politique de Santé dans le Brésil Démocratique (1985-1998)

L'article évalue la dynamique du processus décisionnel de la politique de santé au Brésil à partir de la relation Exécutif-Législatif. Examine les mécanismes institutionnels, les stratégies de négociation et les ressources politiques que les présidents et les parlementaires ont en mains pour introduire, modifier et réglementer les lois dans ce domaine social. Il constate que la capacité du Congrès National à lapider la législation que l'Exécutif est chargée de déclencher reste encore limitée (ceci est du, notammment, aux mesures provisoires et au pouvoir de veto de l'Exécutif), mais il conclut que la force législative des présidents dans le domaine de la santé doit être relativisée. En fin de comptes, pendant la période analysée (1985-1998), le Congrès National a démontré une force suffisante pour approuver un nombre croissant de projets de loi et un nombre de projets d'amendements constitutionnels dans ce domaine de la santé beaucoup plus important que l'Exécutif.

Mots-clé: politique de santé; relation Exécutif-Législatif; processus décisionnel; Brésil démocratique 